Portland State University

PDXScholar

\title{
A Comparison of Characteristics of Terminated AFDC Cases with Cases Remaining Active from the June 1966 AFDC Load in Linn County, Oregon
}

William Everett Lowther

Portland State University

Follow this and additional works at: https://pdxscholar.library.pdx.edu/open_access_etds

Part of the Social Welfare Commons, and the Social Work Commons

Let us know how access to this document benefits you.

\section{Recommended Citation}

Lowther, William Everett, "A Comparison of Characteristics of Terminated AFDC Cases with Cases Remaining Active from the June 1966 AFDC Load in Linn County, Oregon" (1968). Dissertations and Theses. Paper 768.

https://doi.org/10.15760/etd.768

This Thesis is brought to you for free and open access. It has been accepted for inclusion in Dissertations and Theses by an authorized administrator of PDXScholar. Please contact us if we can make this document more accessible: pdxscholar@pdx.edu. 


\section{AN ABSTRACT OF THE THESIS OF}

WILLIAM EVERETT LOWTHER for the $\frac{\text { MASTERS }}{\text { (Degree) }}$
in SOCIAL of student) $\quad$ presented on Aprit 22,1968

Title: A COMPARISON OF CHARACTERISTICS OF TERMINATED

AFDC CASES WITH CASES REMAINING ACTIVE FROM

THE JUNE 1966 AFDC LOAD IN LINN COUNTY, OREGON

Abstract approved:

A study of the characteristics of AFDC cases active in Linn County, Oregon in June 1966 and of the difference in characteristics between those cases closed by September 1, 1967, and those cases remaining active on that date. The source of data was the case records of the Linn County Department of Public Welfare. There were 212 cases in the study with 200 suitable for full analysis.

The purpose of this study was to test the hypothesis that there is a difference in selected characteristics between cases remaining active and cases that close. Case records were read and then characteristics tallied. The cases that were in closed status at the end of 15 months were compared with the characteristics of the cases remaining active.

Findings confirmed the hypothesis with respect to two 
characteristics in which there were statistically significant differences. These were family composition and work experience. A large family limited the possibility of termination, but experience in a trade increased the probability of termination.

Education level and age of mother were not found to be significant.

The unmarried mother tended to remain active, but this finding was influenced by size of family.

Question was raised about the reliability of information in case records concerning sexual behavior and use of alcohol.

The woman with chronic medical problems was found to have a better than average frequency of termination.

The impact of vocational training and group therapy was not significant for remaining active or terminating. 
A Comparison of Characteristics of Terminated AFDC Cases With Cases Remaining Active from the June 1966 AFDC Load in

Linn County Oregon

by

William Everett Lowther

\author{
A THESIS \\ submitted to \\ Portland State College
}

in partial fulfillment of

the requirements for the

degree of

Master of Social Work

June 1968 


\section{APPROVED:}

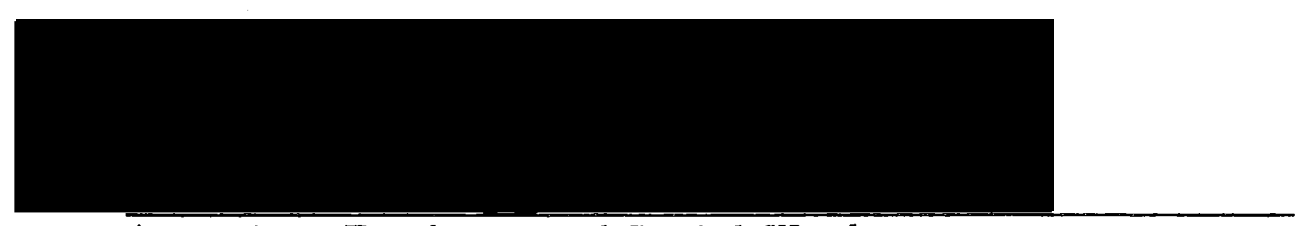

Associate Professor of Social Work
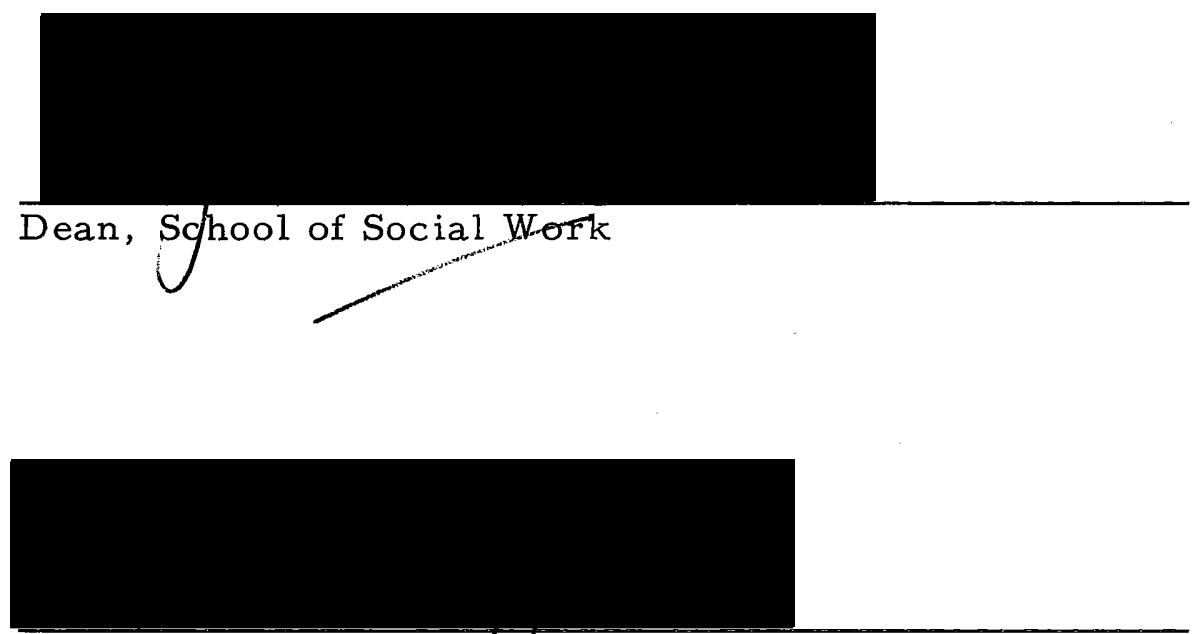

Dean of Graduate Studiles

Date thesis is presented March 29, 1968

Typed by Illa W. Atwood for William Everett Lowther 


\section{ACKNOWLEDGEMENTS}

I wish to express my thanks and appreciation to Mr. Ralph Dunbar, Administrator, Linn County Welfare Commission, for per mission to use the files of the Linn County Welfare Department. I am indebted to Mrs. Kathleen Suklis who typed the initial draft of this study.

My special thanks and appreciation go to the three members of the thesis committee: Kenneth Gervais, Interim Director of Law Enforcement and Associate Director of Urban Studies, Portland State College; Miss Janet L. White, Assistant Professor of Social Work; and my advisor, Frank F. Miles, Associate Professor of Social Work. The encouragement and guidance from Dr. Miles was essential to the completion of this study. 
TABLE OF CONTENTS

I. INTRODUCTION 1

Rationale: Broad Aims of This Study 1

Terminology 2

The Sample 3

Characteristics of the County 3

The Hypothesis 9

II. REVIEW OF THE LITERATURE 10

Summary 16

$\begin{array}{ll}\text { III. METHOD } & 17\end{array}$

Analysis of Hypothesis $\quad 22$

$\begin{array}{ll}\text { Summary } & 23\end{array}$

IV. ANALYSIS $\quad 25$

Education $\quad 25$

$\begin{array}{ll}\text { Work Experience } & 29\end{array}$

Age 33

Family Composition $\quad 35$

Impact of Training or Employment Counseling 37

Unmarried Mothers 41

$\begin{array}{ll}\text { Summary } & 43\end{array}$

V. CONCLUSIONS 45

Unwed Mothers $\quad 53$

Indications for Further Studies $\quad 53$

$\begin{array}{ll}\text { BIBLIOGRAPHY } & 57\end{array}$

$\begin{array}{ll}\text { APPENDIX } & 61\end{array}$ 


\section{LIST OF TABLES}

Population of Selected Counties 4

II Frequency of Low Income Families in Selected Counties

III Rate of Less Than 8 th Grade Education in Selected Counties for Persons 25 and Older for 1960

IV Rate of High School Drop out in Selected Counties for $1963-64$

V AFDC Caseload in Selected Counties in 1964 Arranged by Number of Children under 18

VI Trend of AFDC Load in Linn County July 1962 to July 1967

VII Type of Cases

VIII The Education Level of the Maternal Head of the Home

IX Work Experience of the Maternal Head of the Home

X Family Size of Female Head of Family with

Trade

XI Age of Female Head of Family with Trade

XII Mean Education of Women

XIII Female Head of House with Experience in a Trade - Miscellaneous Variables

XIV Maternal Head of Home - Age 34

XV Size of Family of Female Head of Home 35

XVI Ages of Children of Maternal Head of Home 36 


\section{LIST OF TABLES (continued)}

Page

XVII Status of Case and Ages of Children of Female Head of House Receiving Training and Employment Counseling

XVIII Reason for Termination - Female Head of House Receiving Training and Counseling

XIX Ages of Female Head of Family Receiving Training and Employment Counseling

XX Average Characteristics of Female Head of House Receiving Training and Counseling

XXI Unmarried Mothers

XXII Children of Unmarried Mothers

XXIII Reason for Close - Female Head of House with No Previous Work Experience

XXIV Reason for Close - Female Head of House with Experience in a Trade

XXV Number of Cases in Study

XXVI Table of Means

XXVII Ages of Adults 62

XXVIII Ages of Adults in Grants 62

XXIX Education Level by Age of Female Adults 63

XXX Number of Children Known Ever Born by Age of Child

XXXI Number of Families by Number of Children and Time Since First Application - Closed Cases

XXXII Number of Families by Number of Children and Time Since First Application - Active Cases 


\section{LIST OF TABLES (continued)}

\begin{tabular}{|c|c|c|}
\hline & & Page \\
\hline XXXIII & Number of Children in Grant by Age of Child & 67 \\
\hline XXXIV & Reason for Need & 67 \\
\hline $\mathrm{XXXV}$ & Education - All Adults & 68 \\
\hline XXXVI & Education - Adults in Grant & 69 \\
\hline XXXVII & Work Experience - All Adults & 70 \\
\hline XXXVIII & Work Experience - Adults in Grant & 71 \\
\hline XXXIX & $\begin{array}{l}\text { Education of Female Head of House with } \\
\text { Experience in a Trade }\end{array}$ & 72 \\
\hline $\mathrm{XL}$ & $\begin{array}{l}\text { Number of Illegitimate Children by Size of } \\
\text { Family of Female Head of House with Trade }\end{array}$ & 72 \\
\hline XLI & Adult Behavior Problems & 73 \\
\hline XLII & Number of Children with Child Problems & 74 \\
\hline XLIII & Female Head of House - Size of Family & 75 \\
\hline XLIV & Absent Fathers & 76 \\
\hline$X L V$ & $\begin{array}{l}\text { Number of Children by Age of Mother and Age } \\
\text { of Child in Family with Female Head }\end{array}$ & 77 \\
\hline XLVI & $\begin{array}{l}\text { Number of Mothers by Age of Mother and Age } \\
\text { of Child in Family with Female Head }\end{array}$ & 77 \\
\hline XLVII & Group Treatment & 78 \\
\hline XLVIII & Cases Referred for Vocational Training & 78 \\
\hline XLIX & Reason for Close - All Women & 79 \\
\hline
\end{tabular}


A COMPARISON OF CHARACTERISTICS OF TERMINATED

AFDC CASES WITH CASES REMAINING ACTIVE

FROM THE JUNE 1966 AFDC LOAD IN

LINN COUNTY OREGON

\section{CHAPTER I}

\section{INTRODUCTION}

This report describes some characteristics of recipients of aid to families with dependent children in Linn County, Oregon, comparing the active to the closed cases. The study is limited in scope to recipients who were on assistance by reason of the death, continued absence, or disability of a wage earner.

\section{Rationale: Broad Aims of This Study}

Public assistance has been the method of choice of handling the problem of indigency in this county. There has been much concern expressed about the rising cost of public assistance and the gradually increasing caseload of dependent children (Lynch, May 1967). In recent years, with the support of the federal government, the states have been compelled to intensify services in an effort to reduce the caseload. It is not yet clear whether these efforts are having any particular effect. We have talked a great deal about the need for services to reduce caseloads and to increase the capacity of individuals to be self-sufficient. Cases have opened, and cases 
have closed, and little has been done to determine the interaction of factors to bring on the closing (Miller, 1965). One of the areas of greatest concern has been that group of cases that tend to remain on assistance for long periods of time. It seems reasonable that we try to determine what characteristics these cases might have that are different from the characteristics of cases that terminate assistance. The chief purpose of this study is to contribute some knowledge to the understanding of the characteristics of recipients and possibly make some contribution toward understanding better the programs that might be effective in helping to reduce the caseload. While looking at the characteristics, we will also endeavor to assess some of the service components in the program in the county and attempt to evaluate the characteristics of the clients with whom these programs are effective.

\section{Terminology}

The term AFDC has come to be common usage and is generally understood. In this study we will be referring to aid to families with dependent children. The term recipient will be used in reference to a person receiving public assistance and will be specifically referring to the adult payee of the grant. 


\section{The Sample}

The sample consists of all of the cases that were actively receiving aid to families with dependent children by reason of the death, continued ab sence or disability of a parent in June of 1966 in Linn County, Oregon. There were 240 cases read, but only 212 of these fit the criteria for the study. Those eliminated were either recipients of AFDC by reason of the unemployment of the employable wage earner or were foster care situations in which both parents were absent from the home. This study does include two cases in which both parents were absent. However, in both cases a parent was considered to be in the home because the absence was by reason of a temporary problem that was expected to be alleviated. In one instance the mother had remarried and had temporarily left the children with a relative. In the other instance the mother was sick and receiving medical care.

\section{Characteristics of the County}

Linn County, Oregon is located in the mid-Willamette Valley about 70 miles south of Portland. It is bounded on the west by Benton County, on the north by Marion County, on the east by Deschutes County, and on the south by Lane County. The most populous county in the state of Oregon is Multnomah. For better understanding of the 
economic situation, we are including three tables of indices (Hatfield \& Oberdorf, 1965). It can be noted from Table I that Linn County's population, as well as that of the other counties, has been increasing. Linn County ranks eighth in the state in population, but is ranked 15 th in level of poverty.

TABLE I

POPULATION OF SELECTED COUNTIES

\begin{tabular}{lccc}
\hline & Total Pop. 1960 & Total Pop. 1964 & Rank Order \\
\hline Linn & 58,867 & 64,029 & 8 \\
Lane & 162,890 & 190,072 & 2 \\
Benton & 39,165 & 45,666 & 11 \\
Marion & 120,888 & 139,301 & 3 \\
Multnomah & 522,801 & 541,386 & 1 \\
\hline
\end{tabular}

From Tables III and IV it can be noted that $11.6 \%$ of persons over age 25 had less than an 8 th-grade education and $3.3 \%$ of high school students drop out before graduation.

From Table V it can be seen that the average monthly AFDC load in 1964 was 230 cases. Although Linn County ranks eighth in population, it ranks 12 th in average caseload.

Linn County has a diverse economy. There is a large lumber industry, extensive agriculture, and a rare metals processing 
TABLE II

FREQUENCY OF LOW INCOME FAMILIES IN SELECTED COUNTIES 1960

\begin{tabular}{lcccc}
\hline & $\begin{array}{c}\text { Total } \\
\text { Families }\end{array}$ & $\begin{array}{c}\text { No. Families } \\
\text { Income } \\
\text { under } \$ 3,000\end{array}$ & $\begin{array}{c}\text { Incomilies } \\
\text { than } \$ 3,000\end{array}$ & $\begin{array}{c}\text { Onk } \\
\text { Linn }\end{array}$ \\
\hline Lane & 15,363 & 2,917 & 18.9 & 15 \\
Benton & 42,014 & 6,132 & 14.5 & 29.5 \\
Marion & 9,299 & 1,548 & 16.6 & 21 \\
Multnomah & 136,561 & 6,065 & 20.9 & 10 \\
\hline
\end{tabular}

TABLE III

RATE OF LESS THAN 8 TH GRADE EDUCATION IN SELECTED COUNTIES FOR PERSONS 25 AND OLDER FOR 1960

\begin{tabular}{lccc}
\hline & $\begin{array}{c}\text { \# Persons } \\
25 \text { and over }\end{array}$ & $\begin{array}{c}\% \text { Persons } 25 \text { and over } \\
\text { with less than } 8 \text { yrs. } \\
\text { Education }\end{array}$ & $\begin{array}{c}\text { Rank } \\
\text { Order }\end{array}$ \\
\hline Linn & 31,365 & 11.6 & 22 \\
Benton & 85,282 & 10.1 & 33 \\
Marion & 18,263 & 8.6 & 36 \\
Multnomah & 68,891 & 15 & 21 \\
\hline
\end{tabular}


TABLE IV

RATE OF HIGH SCHOOL DROPOUT IN SELECTED COUNTIES FOR 1963-64

\begin{tabular}{lccc}
\hline & $\begin{array}{c}\text { High School } \\
\text { Enrollment }\end{array}$ & $\begin{array}{c}\text { \% Dropped out of } \\
\text { High School }\end{array}$ & $\begin{array}{c}\text { Rank } \\
\text { Order }\end{array}$ \\
\hline Linn & 5,120 & 3.3 & 12 \\
Lane & 13,315 & 2.5 & 20.5 \\
Benton & 2,675 & 3.2 & 15 \\
Marion & 9,034 & 2.9 & 16 \\
Multnomah & 34,209 & 3.3 & 12 \\
\hline
\end{tabular}

TABLE V

AFDC CASELOAD IN SELECTED COUNTIES IN 1964 ARRANGED BY, NUMBER OF CHILDREN UNDER 18

\begin{tabular}{lccc}
\hline & Children & $\begin{array}{c}\text { AFDC } \\
\text { Cases }\end{array}$ & $\begin{array}{c}\text { Rank on } \\
\text { Number } \\
\text { of Cases }\end{array}$ \\
\hline Linn & 25,163 & 230 & 12 \\
Lane & 70,327 & 587 & 2 \\
Benton & 14,895 & 50 & 20 \\
Marion & 48,895 & 566 & 1 \\
Multnomah & 176,492 & 3020 & 3 \\
\hline
\end{tabular}


industry. Agriculture and the allied food processing industries are sea sonal.

There are three main centers of population. Albany, the county seat, is the largest with a population of 16,500; Lebanon is second with a population of 6,300 ; and Sweet Home is third with a population of 4,000 (Oregon Blue Book 1967-68). There are a number of rural towns and post offices sprinkled throughout the county.

The Linn County Welfare Department has a staff of 25 caseworkers, none of them having the professional degree. Resources for social services are limited. The Linn County Mental Health Clinic, with a staff of five trained workers, is about the only service available in the county. The juvenile court is still subject to the jurisdiction of the county judge although it is now in transition to the circuit court. Portland, about 70 miles to the north, has a number of services that provide statewide coverage available to Linn County residents; for example, Crippled Children's Division, Medical School Clinic, and a number of institutions for the care and treatment of children.

From Table VI it is clear that the caseload in Linn County has been showing a rising trend over the past several years. There has been much fluctuation due to the seasonal nature of agriculture, one of the principal industries. The winter of 1966-67 show s a high peak because some construction on a dam on the South Santiam River had 
TABLE VI

TREND OF AFDC LOAD IN LINN COUNTY ${ }^{l}$

\begin{tabular}{lcccccccccc}
\hline July & Jan. & July & Jan. & July & Jan. & July & Jan. & July & Jan. & July \\
1962 & 1963 & 1963 & 1964 & 1964 & 1965 & 1965 & 1966 & 1966 & 1967 & 1967 \\
\hline 752 & 1237 & 955 & 952 & 851 & 1106 & 973 & 1271 & 1043 & 1415 & 1180 \\
\hline
\end{tabular}

${ }^{1}$ Source: Oregon State Welfare Department

just been completed and some lumber mills had closed, resulting in a higher than usual unemployment problem.

Cases were classified into three categories: intensive service, environmental service, and regular service. The intensive service caseloads were limited to 35 cases; the environmental service caseloads, 60 cases; and the regular service loads, 120. Most AFDC cases were in either intensive service or environmental service caseloads.

Beside financial assistance, there were three services offered by the Welfare Department. First was counseling, which was offered on an individual basis as time was available. There was a minimum requirement of one contact per month for cases requiring services. Those not receiving such intensive services had to be seen at least every six months. The second service offered was employment counseling and training involving upgrading of the educational level. 
The third service was group counseling. In September of 1966 the Linn County Welfare Department became the recipient of a Federal grant to demonstrate the use of groups in public welfare. The kinds of groups used were: AFDC mothers problem group, in which the clients were encouraged to develop relationships and discuss their problems; pre-training groups to help those whom the department felt should be considering employment but at that point had not developed realistic plans; and in-training groups for women who were in training and planning on employment in the near future.

\section{The Hypothesis}

The working theoretical hypothesis of the study was that there was a difference in characteristics between those cases that had terminated by the end of a 15-month period and those that had not. As sub-hypotheses it was thought that cases that remained active with the agency more than 15 months would have larger families, have less education, would have poor work experience, and there would be an age difference. 
CHAPTER II

\section{A REVIEW OF THE LITERATURE}

A great deal has been written on the problem of poverty. The Public Affairs Information Service lists 246 books, articles, and reports on the subject of public welfare alone. In discussing the St. Paul family-centered project, Birt observed they had found that $6 \%$ of the families used $50 \%$ of the social services that are available (Oct. 1956). There seems to be a shortage of studies that would define characteristics and their impact on the welfare caseload (Miller, 1965). We have been able to find only three studies that seemed comprehensive. From a review of the Abstract on Research (Bureau of Family Services) between January of 1957 and June of 1964, we were able to find only one project listed that studied AFDC families and children. We were unable to obtain any more current information.

Of the three studies we were able to find that researched characteristics of AFDC cases the first was sponsored by APWA and studied terminated cases (Blackwell and Gould, 1952). The second was by Greenleigh Associates (1960) and studied ADC in Cook County, Illinois. The other was by Burgess and Price, studying a nationwide sample of terminated cases (Burgess, Jan. 1965). Blackwell and Gould (1952) examined AFDC cases from application 
to termination. They found that short-term assistance was characterized by age. Parents and children were younger than those who tended to be on for long periods of time. They found that the fathers in these cases were frequently in the lower-ranking occupations and that the mothers tended to be in either clerical, sales, or domestic types of employment, but only about half of the mothers worked. They found that unmarried mothers tended to be on slightly less than the median or average period of time. They excluded from their study cases that had been on assistance for less than a year. They found that only $11 \%$ of their study had been on assistance as long as seven years.

Burgess and Price and the Greenleigh Associates' studies were compared by Henry Miller (Dec. 1965). He found it difficult to make any conclusions from the se two studies because 1) definitions did not seem clear, and 2) their findings did seem at variance. He concluded, however, after comparing both of these studies, that they showed no solid evidence of juvenile delinquency as being more prevalent among AFDC cases than in the general population. He found little reliable data to support the contention that mental illness is more prevalent in AFDC cases than in the general population. He felt the information on mental retardation was unreliable but did seem to indicate that it is probably higher in most AFDC cases than in the general population. He found no substantial evidence to support the 
contention that alcoholism is more prevalent in AFDC. He did find that illegitimacy appears to be higher in AFDC cases although the findings of the two studies conflict. There was nothing in either study on the life style of AFDC cases.

Mr. Miller concluded that, after 30 years of Social Security, we know little about the characteristics of AFDC cases except they are fatherless and poor. He ended by urging that more research is needed; without it, social work has no way of establishing goals.

Alvin Schor $\mathbf{1}$ (1966) endeavored to bring to the attention of the public the plight of children and possible remedies. He cited government statistics and made conclusions from these. He pointed out that children are poor because their parents married young, were uneducated, and had too many children.

Geismar (1960), in reviewing the studies done by such organizations as New York Youth Board, St. Paul family-centered project, and Community Research Associates, Inc., stated,

Thus we have become aware of the fact that the multiproblem urban family in comparison with the non-problem family has more children, is headed by mothers who mar ried younger and by fathers who are conspicuous by their frequent or permanent absence from the home, and have more youngsters in the home who are offspring from unions other than that of parents heading the family (grandchildren, children of paramours or deceased relatives, children from earlier unions of one or both of the marriage partners, etc. (page 168)

He points out that the higher incidence of divorce, illegitimacy, child 
neglect, juvenile delinquency, disordered adult behavior, and psychiatric and correctional institutionalizations has been reasonably well documented. He did not cite specific references.

Carol Myers (May 1963) listed characteristics of multiproblem families that she felt were obvious though she offers no studies to support her observations. She felt that periodic unemployment, indebtedness, inadequate housing, poor standards of housekeeping, conspicuous marital discord, school failure, delinquency and other major misconduct, chronic illness, alcoholism, narcotics addiction, and prostitution are all prominent characteris tics to be found in public assistance families. She felt that public assistance families would also be characterized by repetition in succeeding generations, long contact with social agencies, pervasiveness of their personal and social breakdown, and trouble to the community in which they lived. She felt they would be resistant to offers of help from social workers and disinclined to ask for services. She felt that in order to help them they must be individualized and would require the use of some very fundamental casework methods.

A review of the literature on poverty indicated that there are many assumptions about welfare recipients. Norman V. Lourie, writing in Social Work and Social Problems (Cohen, ed., 1964) states, 
Economist Boulding makes a distinction between poverty that is the result of some peculiar accident or venture and chronic poverty. He contends that chronic poverty is always in some meaningful sense a condition of society or of a sub-culture within society and that within wide limits poverty is a state of mind more than income.

$\mathrm{He}$ is saying here that there is a difference between those who are chronically poor and those who are poor for a temporary period, but attributes this difference to social or cultural factors. He makes no attempt to define characteristics.

John Kenneth Galbraith maintained that poverty, as a condition of our society, is pretty well eliminated. Poverty that exists now is the result of some individual quality, such as mental deficiency or inadequate education, and insular poverty, which is resulting from unwillingness or inability to leave a chronically poor community. Michael Harrington (1962) took Mr. Galbraith to task for what he considered to be his limited understanding of the problem of poverty and presented a cogent picture of poverty in this country. He developed the thesis of the invisible poor, pointing out that they are with us but are not as visible as we might expect them to be. He describes them as he has known them and cites government statistics to back up his contention that poverty is more prevalent than we believe.

In the first annual conference on social is sues at the University of Oregon in Eugene (Jan. 27, 28, 1966) Robert Lampman attempted 
to describe the characteristics of poverty. He states that more than one-third of the contemporary poor are in families headed by a person not in the labor force at any time during the year. About $40 \%$ of the income of the poor today is made up of transfer payments such as unemployment, old age assistance, and various types of income. He states that among the characteristics of the poor, at least onefifth of the adults and one-third of the children are non-white. He states the leading characteristic which distinguishes the poor family head from the non-poor is the limited educational attainment. Threefifths of the family heads have no more than an 8 th-grade education. Another important point is that about half the poor are in the South. He states that unemployment is about $4.1 \%$ of the total population and about $6 \%$ for the poor population. He stressed that unemployment and poverty are two different problems--two different issues. Several studies have attempted to define universal character istics. There seems to be some differences among them. For example, poverty on the national level seems to be characterized by a high proportion of Negroes; yet, when examining poverty in the far West, Burgess (1965) found that Negroes were not disproportionally represented in the poverty picture. 


\section{Summary}

Writers on the subject of poverty presume many characteristics and ascribe to them a national significance. There is reason to question the validity of these assumptions. These characteristics probably do exist and may be prevalent in some areas, such as Negroes in the South and some highly industrialized urban centers in the North, but is it valid to assume the same characteristics exist everywhere? This question can only be resolved with a series of regional studies. Poverty is a condition of society. If we are to mount effective programs to alleviate this condition, it is important to understand it. So far we have ignored a thorough diagnostic appraisal of the situation. 


\section{CHAPTER III}

\section{METHOD}

The method of studying was a method of tallying characteristics that were clearly available from case records. The records active for the month of June, 1966 were pulled and read. A sheet of 16column ledger paper was used, placing the characteristic s to be tallied at the top of the sheet and tallying columns with the family members listed in the left-hand column. This method was not entirely satisfactory. It was necessary to tally separately for the age of adults and length of time since first application. It worked very well for the other characteristics, however.

In tallying the ages of children, the age ranges used by the Welfare Department in computing grants were used except that the two lower categories, 0 to 3 and 4 to 6 , were combined as the children most needful of the mother's presence in the home. The full caseload of AFDC cases for one month was selected because this would provide a good cohort of cases for follow-up study of closing although with some sacrifice of randomness. Cases active for the month of June, 1966 were chosen because they were available. Only cases on assistance by reason of the death, disability, or continued absence of a parent were used because it was felt that cases on assistance by reason of unemployment, alone, represent an entirely 
different problem. There were several cases inadvertently included in the study that were subsequently eliminated, several for reason of not receiving AFDC during the month of June, and there was a number of others that were technically foster care cases. There was a total of 212 cases included in the study. Of these cases $134 \mathrm{r}$ emained active as of September 1967; 66 had closed; and 12 cases transferred to other counties.

In selecting characteristics for the study there was one overriding consideration. The characteristics to be studied must have been consistently recorded in the case record. An effort was made to obtain information on behavioral characteristics, notably alcoholism and sexual behavior, but this was not productive of reliable data.

Characteristics selected were listed across the top of a $16-$ column sheet of ledger paper, assigning two variables to a column and so splitting each column. Space was left at the bottom for tallying each sheet.

The face sheet is the first form one sees when opening a case record. From this form it is possible to obtain the name, sex, and age of all individuals listed in the family at the time of application. This information had to be checked against the most recent budget, which is filed elsewhere in the office, to determine the current family composition. Education level of adults was often on the face sheet, but if not, could be found in the narrative. There were three 
cases in which this information was not in the record. Under the face sheet is filed a handwritten social diagnosis prepared by the case worker. Under this are the eligibility forms containing verifications of age, residence, and reason for need. From the se forms was obtained the reason for need, the marital status of the mother at the birth of each child, and whether either parent was in jail at the time of application. Reason for need was only tallied for the most recent marriage, ther efore the reason for need may not apply for all children in a family.

The narrative, often quite bulky, is filed under the eligibility forms. The narrative contains the recording of the intake interview and subsequent casework contacts. It was necessary to look to the narrative for the work experience of the adults in the family and for behavior problems. It was also possible to find information on child support here though it was also available elsewhere in the record.

In selecting characteristics 10 records were selected at random and characteristics consistently available were listed. Education level of children, one characteristic thought desirable for correlation with age, was not consistently recorded. It was also found impossible to determine marital history. Fathers of children were recorded, but other marriages were not or were only ca sually mentioned. Marriage dates were often vague or not recorded. Legitimacy of children was sometimes difficult to determine. Those cases 
in which there was no doubt were clearly and consistently recorded, and tallies were restricted to those instances. From the initial survey it was thought that current employment status would be significant; but because of an inadequate definition, tallying became confused and was abandoned. There were many instances of occasional work of a temporary nature, and it was often impossible to tell if the client were currently employed. Information on regular employment was obtained later for some specific cases that had received vocational training, but it was not possible to obtain this information for the full cohort of cases because of lack of time.

It was not posible to obtain reliable and consistent information about absent fathers.

The characteristics finally selected for study were ages of adults, ages of children, family composition reason for assistance, marital status, education of adults, work experience, selected behavior problems of adults and children, and support from absent parents. A count was also made of those cases in which the parents were still married but one or the other was in jail.

Behavior problems included sexual promiscuity, drinking problem, chronic medical problem, truancy and record of delinquent behavior. It was necessary to rely entirely on the narrative for most of this information. It is believed that the information on chronic medical problems is accurate and complete. It was possible 
to check this information against a record of the use of medical services. The intake narrative always contained information supplied by the recipient on the health status of each member of the family.

Truancy was only recorded if it came to the attention of the caseworker and was usually a severe problem.

Other delinquent behavior, like truancy, was only recorded when it came to the attention of the worker and was usually severe. Adult delinquent behavior was also studied. For both adults and children a tally was made if there were any history of delinquent behavior. Such behavior included stealing, running away, fire setting, persistent traffic violations, and various other infractions of the law.

The determination of sexually promiscuous behavior and problem drinking was difficult. It was necessary to rely entirely on opinions recorded by caseworkers. There was no uniform treatment of these variables in the records. It was felt desirable to study these variables to see if there was any relationship between recording of this information and the tendency of a case to remain active.

In September of 1967, when the data was reorganized into active and closed cases, additional information was obtained. Instances of referral to group treatment and vocational training were noted to test the impact of these programs on closing. Reason 
for closing was also obtained. Cases transferred to other counties were removed from the analysis because it was not possible to determine whether they remained active or had closed.

Because this is a study of a total universe of cases, a descriptive analysis of the variables with a chi-square test of significance will be used to test the null hypothesis.

It had originally been intended to test for closing at the end of one year, which would have been June of 1967 . It was not possible to obtain a list of the closings at that time. It was September before a list could be obtained; and as that list included cases terminated by September 1, 1967, it was decided as a matter of expedience to extend the study to that date. If a case was open on September 1 , 1967, it was considered an active case, and if it was closed on that date, it was considered a closed case.

Tables not essential to the analysis are available in the appendix and will be referred to as pertinent.

\section{Analysis of Hypothesis}

The major hypothesis is that there will be a difference in the characteristics of cases remaining active after September 1, 1967 , and cases closed by that date. It was found that $67 \%$ of the cases remained active to $33 \%$ that closed. This relationship will be used as a norm to test for the tendency of a variable to weigh toward 
either remaining active or closing. The chi-square test will be used to test for significance.

The most prevalent type of case was that of the maternal head of the family. They comprised $79 \%$ of the total load and showed the same active to closed ratio as the total caseload (Table VII).

TABLE VII

TYPE OF CASES

\begin{tabular}{lcccc}
\hline Head of Household & $\mathrm{N}$ & Total & Active & Closed \\
\hline Female head of house & 158 & 79.0 & $67.1 \%$ & $32.9 \%$ \\
Male head of house & 3 & 1.5 & $33.3 \%$ & $66.6 \%$ \\
Both parents present & 39 & 19.5 & $69.2 \%$ & $30.8 \%$ \\
Total all cases & 200 & 100.0 & $67.0 \%$ & $33.0 \%$ \\
\hline
\end{tabular}

Because of the prevalence of the female as the one parent head of the house, the testing of the hypothesis was restricted to these cases.

\section{$\underline{\text { Summary }}$}

This is a study of AFDC cases active in June 1966 in Linn County, Oregon. There were 212 cases in the study, of which 134 remained active at the end of 15 months, 66 closed, and 12 
transferred out of county. The 12 cases that transferred were not analysed because it was not possible to identify them as open or closed by the test date of September 1, 1967.

Information uniformly available in the case records of the Linn County, Oregon welfare office was tallied for nine general characteristics.

It was found that $67 \%$ of all cases remained active on the test date and $33 \%$ closed. The most prevalent type of case was that with a maternal head of the home. This type of case showed the same ratio of opening to closing as the total study and represented $79 \%$ of all the cases. The analysis was restricted to this type of case. The ratio of closing for the total cases of $2 / 3$ active to $1 / 3$ closed was used as a norm of comparison to test the influence of specific variables. The chi-square test was used for significance.

The general hypothesis was that there would be a difference between the characteristics of the active and closed cases. 
CHAPTER IV

ANALYSIS

\section{Education}

The education level is not as significant in influencing the closing of cases as might have been expected (Table VIII).

\section{TABLE VIII}

THE EDUCATION LEVEL OF THE MATERNAL HEAD OF THE HOME

\begin{tabular}{lcccccc} 
& \multicolumn{2}{c}{ Active } & \multicolumn{2}{c}{ Closed } & \multicolumn{2}{c}{ Total } \\
& $\mathrm{N}$ & $\%$ & $\mathrm{~N}$ & $\%$ & $\mathrm{~N}$ & $\%$ \\
\hline Less than 8th grade & 15 & 86.6 & 3 & 13.4 & 18 & 11.4 \\
8th grade & 16 & 69.6 & 7 & 30.4 & 23 & 14.6 \\
9th through 11th & 50 & 66.6 & 25 & 33.3 & 75 & 47.5 \\
12th grade & 17 & 54.8 & 14 & 45.2 & 31 & 19.6 \\
More than 12 th & 6 & 75 & 2 & 25 & 3 & 5 \\
Unknown & 2 & & 1 & & 3 & \\
\hline
\end{tabular}

An analysis of Table VIII yields a chi square of 4.556 with four degrees of freedom. This is not significant at the .05 level. Therefore the null hypothesis must be accepted. However from the relative percentages it is evident that there is a slight tendency for less 
educated women to remain on assistance with a decreasing tendency through the 12 th grade. Women with more than a 12 th-grade education tended to remain active.

As a matter of interest I looked at the cases of women with more than a 12 th-grade education in more detail. Of the two that closed one was 21-years old and one was 45. The 21 -year-old woman had one pre-school-age child and had vocational training. She had been on assistance over three years and terminated by getting married. The 45-year-old woman had two children, one older teenage and one pre-teen. She had some college education but had a chronic medical problem. Her oldest child was over age to include in assistance, and the youngest one was sent to the boy's training school--which terminated her eligibility for assistance. Both of these women were resistant to accepting employment although both had worked as waitresses before as sistance.

Of the six remaining active, three had some college and three had vocational training. Of the three with vocational training, none had ever worked. Their ages were 25,34 , and 47 .

The 25-year-old woman had been on assistance for less than a year, was divorced, and received no support from her ex-husband. Although offered training, she refused it. She had two pre-school children and felt she could not leave them.

The 34-year-old woman was an Oriental who had been ostracized 
by her people because she formed a common-law relationship with a Caucasian male. She had five children by him, four pre-school age and one pre-teenage. She participated in groups and accepted training; but when faced with having to leave the community where she had lived for many years to look for work, she refused. The father of her children left her to marry a Caucasian woman, and she had remained bitter, insisting he should be forced to return and take care of her and the children.

The 47-year-old woman had two pre-school children, two teenage and two older teenage. She has been married twice and receives support for five children by her first husband. She refused training, maintaining her children needed her at home.

Of the three women with some college education, all had worked in the past as waitresses. One was 21 years old, one was 26 , and one was 35.

The 21 -year-old woman had never married and had two preschool-age children. She had a history of sexual promiscuity. She had been on assistance a very short time but was not considered a good candidate for training.

The 26-year-old woman was separated from her husband and had three pre-school-age children. She had received nurses aid training through the Welfare Department but could not find satisfactory child care--so could not work. Her caseworker felt she did not 
want to find child care. Because of the ages of her children, she was permitted to remain on assistance.

The 35-year-old woman was divorced and has one pre-schoolage child, three pre-teenagers, and one teenager. She received some support from her ex-husband. She had the intellectual capacity to do college work. The Welfare Department put considerable effort into helping her complete her college work. She lived in the country on a small acreage and refused to move. She commuted 20 miles round trip daily for several years to try to finish her college work, but finally failed because of low grades. Her children demanded too much of her time. She had talked a great deal about wanting to be a school teacher. She gave this up and now talks of her dedication to her children.

All six of these women clung to their children. They verbalized how much their children needed them. They did not feel it would be fair to their children for them to work. They had all suffered considerable frustration in their lives and seemed to be clinging to their children as the only sure gratification of their needs.

Similar variables may operate among those of lower education. We can reason that as education and associated abilities rise and people remain incapacitated, remaining variables must be stronger. Some with lower education may have equally strong inhibiting traits obscured until the ostensible ones are successfully treated. Further 
analysis might be revealing, but would require more depth than is possible in this study.

\section{Work Experience}

Work experience is divided into three general areas: labour, trade, and no experience. Laborer experience includes field work, housework, and cannery work. The trade category includes waitress work, nurses aide, and office work. Women with only baby-sitting experience were placed in the no-experience category (Table IX).

TABLE IX

WORK EXPERIENCE OF THE MATERNAL HEAD OF THE HOME

\begin{tabular}{lcccccc}
\hline \multirow{2}{*}{ Work Experience } & \multicolumn{2}{c}{ Active } & \multicolumn{2}{c}{ Closed } & \multicolumn{2}{c}{ Total } \\
& $\mathrm{N}$ & $\%$ & $\mathrm{~N}$ & $\%$ & $\mathrm{~N}$ & $\%$ \\
\hline Laborer & 13 & 81,2 & 3 & 18.8 & 16 & 10.1 \\
No experience & 70 & 72.9 & 26 & 27.1 & 96 & 60.8 \\
Trade & 21 & 48.8 & 22 & 51.2 & 43 & 27.2 \\
Unknown & 2 & & 1 & & 3 & \\
\hline
\end{tabular}

The chi square for Table IX is 9.364 with two degrees of freedom and is significant at the .05 level. Therefore the null hypothesis must be rejected.

Ninety-six of the 158 women, or $60.8 \%$, had no work 
experience. They had a greater than expected tendency to remain active. The theoretical frequency for active cases was 10.7 to an observed frequency of 13 .

The most clearly significant finding from Table IX is the tendency for women with experience in a trade to close. They comprise $27.2 \%$ or 43 of the women. The expected frequency to remain active was $48.8 \%$ with an observed frequency of 2.1 .

Although the number of cases of women with experience in a trade is too small to make significant comparisons, it is interesting to compare this one variable with family size (Table X), age of the women (Table XI), and average education (Table XII) to see what questions might be formulated.

It may be noted that the families tended to be small. No cases closed if there were more than four children, but $79 \%$ of the cases had three or less children (Table X).

By breaking down Table $X$ to a two-by-two table, putting the one and two child families in the first cell and the three or more child families in the second cell, a chi square is obtained of 1.144 with one degree of freedom. This is not significant at the .05 level. It must be concluded that the number of children of women with experience in a trade was not a significant variable for opening or closing.

Although $48.8 \%$ or 21 of the women were between 20 and 29 
TABLE $X$

FAMILY SIZE OF FEMALE HEAD OF FAMILY WITH TRADE

\begin{tabular}{|c|c|c|c|c|c|c|}
\hline \multirow{3}{*}{$\begin{array}{l}\text { Number of } \\
\text { Children } \\
\text { in Family }\end{array}$} & \multicolumn{6}{|c|}{ Families } \\
\hline & \multicolumn{2}{|c|}{ Active } & \multicolumn{2}{|c|}{ Closed } & \multicolumn{2}{|c|}{ Total } \\
\hline & $N$ & $\%$ & $\mathrm{~N}$ & $\%$ & $\mathrm{~N}$ & $\%$ \\
\hline 1 & 6 & 46.1 & 7 & 54.9 & 13 & 30.2 \\
\hline 2 & 3 & 33.3 & 6 & 66.6 & 9 & 20.9 \\
\hline 3 & 6 & 50.0 & 6 & 50.0 & 12 & 27.9 \\
\hline 4 & 2 & 40.0 & 3 & 60.0 & 5 & 11.6 \\
\hline 5 & 3 & 100.0 & 0 & 00.0 & 3 & 7.0 \\
\hline 6 & 1 & 100.0 & 0 & 00.0 & 1 & 2.3 \\
\hline $\begin{array}{l}\text { Mean number } \\
\text { children per } \\
\text { family }\end{array}$ & 2.8 & & 2.3 & & 2.6 & \\
\hline
\end{tabular}

years of age, they showed no tendency to close compared to the norm for the study of $67 \%$ active to $33 \%$ closed (Table XI). A trend toward closing does appear in the older age ranges of 30 to 49 in which we find $44.4 \%$ or 19 of the women.

By reducing Table XI to a two-by-two table, dividing between 29 and 30 years of age, a chi square of 2.836 with one degree of freedom is obtained. This is not quite enough to be significant at the .05 level. Therefore with some reservations, noting the obvious trend already mentioned, it must be assumed that the age of the 
TABLE XI

AGE OF FEMALE HEAD OF FAMILY WITH TRADE

\begin{tabular}{lcccccc}
\hline \multirow{2}{*}{ Age Range } & \multicolumn{2}{c}{ Active } & \multicolumn{2}{c}{ Closed } & \multicolumn{2}{c}{ Total } \\
& $\mathrm{N}$ & $\%$ & $\mathrm{~N}$ & $\%$ & $\mathrm{~N}$ & $\%$ \\
\hline Under 20 & 0 & 00.0 & 2 & 100.0 & 2 & 4.6 \\
$20-29$ inc. & 14 & 66.6 & 7 & 33.3 & 21 & 48.8 \\
$30-39$ inc, & 4 & 33.3 & 8 & 66.6 & 12 & 27.9 \\
$40-49$ inc. & 3 & 42.8 & 4 & 57.2 & 7 & 16.3 \\
$50-59$ inc. & 0 & 00.0 & 1 & 100.0 & 1 & 2.3 \\
Mean age & 28.7 & & 33 & & 30.2 & \\
Range & $20-46$ & & $19-50$ & & $19-50$ & \\
\hline
\end{tabular}

women is not a significant variable for opening or closing.

The education level of the women with experience in a trade was generally higher than the education level for women in the total study (Table XII).

TABLE XII

MEAN EDUCATION OF WOMEN

\begin{tabular}{lcc}
\hline & Active & Closed \\
\hline Women with experience in a trade & $10.8 \mathrm{yrs}$ & $10.5 \mathrm{yrs}$. \\
All women in study & $9.0 \mathrm{yrs}$. & $9.75 \mathrm{yrs}$. \\
\hline
\end{tabular}


There was little difference between the active and closed cases in the education level of women with experience in a trade (Table XXXIX). By reducing Table XXXIX to a two-by-two table, a chi square of .044 with one degree of freedom is obtained. This is not significant at the .05 level and the null hypothesis must be accepted.

There are several miscellaneous variables that merit comment (Table XIII). The female head of the house with experience in a trade showed a capacity to overcome chronic medical problems as a handicap to closing. The trend is so great toward closing that it would appear the medical problems of these women may actually assist toward closing. On the contrary, if she became an unmarried mother, she remained on assistance. Also, if she were considered sexually promiscuous, she tended to remain on assistance. Receipt of some additional training while on assistance was a positive variable for closing.

\section{Age}

The hypothesis is that there will be a difference in the age of the women between the active and the closed cases (Table XIV).

The chi square for Table XIV is 5.909 with 4 degrees of freedom. This is not significant at the .05 level and we must accept the null hypothesis. There are some reservations about this however. There is a relative difference that is obvious in the percentages. 
TABLE XIII

FEMALE HEAD OF HOUSE WITH EXPERIENCE IN A TRADE MISCELLANEOUS VARIABLES

\begin{tabular}{|c|c|c|c|c|}
\hline \multirow{2}{*}{ Variables } & \multirow{2}{*}{ Active } & \multirow{2}{*}{ Closed } & \multicolumn{2}{|c|}{ Totals } \\
\hline & & & $\mathrm{N}$ & $\%$ \\
\hline Chronic medical prob. & $40.0 \%$ & $60.0 \%$ & 10 & $25.6 \%$ \\
\hline Unmarried mothers & $100.0 \%$ & $00.0 \%$ & 12 & $30.8 \%$ \\
\hline Sexually promiscuous & $77.7 \%$ & $22.3 \%$ & 9 & $23.1 \%$ \\
\hline Delinquent record & $100.0 \%$ & $00.0 \%$ & 2 & $5.1 \%$ \\
\hline $\begin{array}{l}\text { Received vocational } \\
\text { training }\end{array}$ & $50.0 \%$ & $50.0 \%$ & 8 & $20.5 \%$ \\
\hline
\end{tabular}

TABLE XIV

MATERNAL HEAD OF HOME - AGE

\begin{tabular}{|c|c|c|c|c|c|c|}
\hline \multirow{2}{*}{ Age Range } & \multicolumn{2}{|c|}{ Active } & \multicolumn{2}{|c|}{ Closed } & \multicolumn{2}{|c|}{ Total } \\
\hline & $\mathrm{N}$ & $\%$ & $\mathrm{~N}$ & $\%$ & $\mathrm{~N}$ & $\%$ \\
\hline Under 20 & 3 & 33.3 & 6 & 66.6 & 9 & 5.7 \\
\hline $20-29$ inc. & 37 & 67.3 & 18 & 32.7 & 55 & 35.0 \\
\hline 30-39 inc. & 32 & 68.1 & 15 & 31.9 & 47 & 29.9 \\
\hline 40-49 inc. & 25 & 71.4 & 10 & 28.6 & 35 & 22.5 \\
\hline 50-59 inc. & 9 & 81.8 & 2 & 18.2 & 11 & 6.9 \\
\hline Unknown & 1 & & 0 & & 1 & \\
\hline Mean age & 34.2 & & 31. & & $\therefore \cdots$ & \\
\hline Range & $16-59$ & & $18-$ & & & \\
\hline
\end{tabular}


There are so few cases at the extremes where the difference is most pronounced that randomness might account for them. It is of some interest to note that women under 20 years of age showed a definite tendency to close. There were three cases remaining active and their ages were 16,17 and 18. The cases that closed were either 18 or 19 years of age.

\section{Family Composition}

The hypothesis for family composition was that there would be a difference in size of family between active and closed cases (Table XV).

TABLE XV

SIZE OF FAMILY OF FEMALE HEAD OF HOME

\begin{tabular}{ccccccc}
\hline \multirow{2}{*}{$\begin{array}{c}\text { Number of } \\
\text { Children }\end{array}$} & \multicolumn{2}{c}{ Active } & \multicolumn{2}{c}{ Closed } & \multicolumn{2}{c}{ Total } \\
I & $\mathrm{N}$ & $\%$ & $\mathrm{~N}$ & $\%$ & $\mathrm{~N}$ & $\%$ \\
II & 18 & 51.4 & 15 & 48.6 & 33 & 21.5 \\
III & 18 & 48.8 & 21 & 51.2 & 39 & 25.1 \\
IV & 28 & 76.3 & 8 & 23.7 & 36 & 23.3 \\
V & 13 & 76.5 & 4 & 23.5 & 17 & 10.7 \\
VI or more & 13 & 76.5 & 4 & 23.5 & 17 & 10.7 \\
\hline
\end{tabular}


The chi square for Table XV is 21.098 with 5 degrees of freedom. This is significant at the .05 level and we must reject the null hypothesis. The fewer the children, the greater the tendency to close. The strongest tendency to close exists in those families with only one or two children. If there were more than five children there was no tendency to close.

The ages of the children must also be considered in evaluating the family composition. The hypothesis is that there will be a difference in ages of children between active and closed cases (Table $\mathrm{XVI)}$.

TABLE XVI

AGES OF CHILDREN OF MATERNAL HEAD OF HOME

\begin{tabular}{lccccccc}
\hline \multirow{2}{*}{$\begin{array}{c}\text { Age Range } \\
\text { in Years }\end{array}$} & \multicolumn{2}{c}{ Active } & \multicolumn{2}{c}{ Closed } & \multicolumn{2}{c}{ Total } \\
\hline $0-6$ & $\mathrm{~N}$ & $\%$ & $\mathrm{~N}$ & $\%$ & \multicolumn{2}{c}{$\mathrm{N}$} & $\%$ \\
\hline $7-11$ & 130 & 76.0 & 41 & 24.0 & 171 & 35.8 \\
$12-15$ & 93 & 71.3 & 33 & 28.7 & 126 & 26.5 \\
$16-20$ & 78 & 79.2 & 18 & 20.8 & 96 & 20.8 \\
Over 20 & 57 & 73.1 & 20 & 26.9 & 77 & 16.0 \\
Total & 1 & 33.3 & 2 & 66.6 & 3 & 00.9 \\
Mean age & 9.5 & & 114 & 25.3 & 473 & 100.0 \\
\hline
\end{tabular}


The chi square for Table XVI is 28.707 with 3 degrees of freedom. This is significant at the .05 level, and we must reject the null hypothesis. The ages of the children did not show the distribution expected, however. It was thought the presence of children age six and under would show the most positive relationship to remaining active of any of the age ranges. Instead children in the range of 12 to 15 years of age showed the most positive relationship to remaining active. The theoretical frequency of the 0 to 6 category was 151.5 with an observed frequency of 130--significantly less than expected. The 12 to 15 category had a theoretical frequency of 73. 1 with an observed frequency of $78--$ significantly more than expected.

\section{Impact of Training or Employment Counseling}

Twenty-five of the cases with a maternal head of the home received some form of training or employment counseling. Seventeen of these cases remained active and eight closed. This is a ratio of $68 \%$ active to $32 \%$ closed (Table XVII). However, six of the cases that remained active were helped to find employment even though this was not sufficient to remove them from public assistance. Adding these six to the closed cases, one finds that 14 or $56 \%$ of the cases receiving counseling or training were able to find employment or sufficient resources to reduce or eliminate need for public 
assistance. Of the cases that closed, one closed by reason of getting married and two closed by reason of reconciliation with their husbands. The rest closed because the recipient found employment. However, the one that reconciled and one of those that married had been helped to find jobs before they terminated. Only one of those that closed did not find employment as of the time of closing. She did receive training and was better equipped to find employment (Table XVIII).

The closed cases tended to have children that were older than the cases that remained active. Of children in closed cases, $82 \%$ were over the age of six as compared to $59.6 \%$ of the children in the active cases. Of those active with jobs $65 \%$ of the children were over the age of six (Table XVII).

The number of children in these 25 cases is also an important consideration (Table XVII). The active cases had an average of three children. The active cases with employment had an average of 3.3 children. The closed cases had an average of 2.1 children.

It is interesting to note that the ages of the women in the cases that closed averaged higher than those of the women that remained on assistance (Tables XIX, XX). This is a reversal of the relationship for the total study. The average age was highest for the women remaining active who had jobs. Combine these cases with the closed cases, and we would have a combination of cases that had developed 
TABLE XVII

STATUS OF CASE AND AGES OF CHILDREN OF FEMALE HEAD OF HOUSE RECEIVING TRAINING AND EMPLOYMENT COUNSELING

\begin{tabular}{lcccccc}
\hline $\begin{array}{l}\text { Status of } \\
\text { Case }\end{array}$ & $\begin{array}{c}\text { Number of } \\
\text { Families }\end{array}$ & $0-6$ & $\begin{array}{c}\text { Ages of Children } \\
7-11\end{array}$ & $12-15$ & $16-20$ & Total \\
\hline Active & 17 & 21 & 19 & 9 & 3 & 52 \\
Closed & 8 & 3 & 10 & 3 & 1 & 17 \\
Total & 25 & 24 & 29 & 12 & 4 & 69 \\
Active w/job & 6 & 7 & 5 & 6 & 2 & 20 \\
\hline
\end{tabular}

TABLE XVIII

REASON FOR TERMINATION - FEMALE HEAD OF HOUSE RECEIVING TRAINING AND COUNSELING

\begin{tabular}{lc}
\hline Reason for Termination & Number of Cases \\
\hline Married & 1 \\
Reconciled & 2 \\
Employed & 4 \\
Employed and support from ex-husband & 1 \\
\hline
\end{tabular}

a resource. The difference in ages between the cases that developed a resource and those that did not would be even greater than the difference between the active and closed cases. 
TABLE XIX

AGES OF FEMALE HEAD OF FAMILY RECEIVING TRAINING AND EMPLOYMENT COUNSELING

\begin{tabular}{lcc}
\hline Age Range & Active & Closed \\
\hline Under 20 & 1 & 0 \\
$20-29$ & 6 & 3 \\
$30-39$ & 8 & 3 \\
$40-49$ & 2 & 2 \\
\hline
\end{tabular}

TABLE XX

AVERAGE CHARACTERISTICS OF FEMALE HEAD OF HOUSE RECEIVING TRAINING AND COUNSELING

\begin{tabular}{lccccc}
\hline Status & $\begin{array}{c}\text { Average } \\
\text { Age }\end{array}$ & $\begin{array}{c}\text { Average } \\
\text { Children }\end{array}$ & $\begin{array}{c}\text { Range of } \\
\text { Number of } \\
\text { Children }\end{array}$ & $\begin{array}{c}\text { Time } \\
\text { 1st App. } \\
\text { to 6-66 }\end{array}$ & $\begin{array}{c}\text { Unwed } \\
\text { Mothers }\end{array}$ \\
\hline $\begin{array}{l}\text { Active } \\
\text { Closed }\end{array}$ & 31.2 yrs. & 3.0 & $1-5$ & 4 yrs. 7 mos. & 5 \\
$\begin{array}{l}\text { Active } \\
\text { w/job }\end{array}$ & 35.8 yrs. & 2.1 & $1-3$ & 2 yrs. 2 mos. & 2 \\
\hline
\end{tabular}

There were not enough cases that received counseling or training for any significant findings. The cases we had did raise some interesting questions. Just how significant were training and counseling in influencing the termination of assistance? Did older women 
profit more from training and counseling than younger women? In this study the receipt of training and counseling did help some women to reduce need for public assistance. These tended to be older women. The cases that closed all had small families.

\section{Unmarried Mothers}

In the total universe of cases mothers who were never married were able to terminate assistance at a slightly higher rate than the average for the total study but women with some legitimate children tended to remain active (Table XXI).

TABLE XXI

UNMARRIED MOTHERS

\begin{tabular}{|c|c|c|c|c|c|c|}
\hline & \multicolumn{2}{|c|}{ Active } & \multicolumn{2}{|c|}{ Closed } & \multicolumn{2}{|c|}{ Total } \\
\hline & $\mathrm{N}$ & $\%$ & $\mathrm{~N}$ & $\%$ & $\mathrm{~N}$ & $\%$ \\
\hline Mothers never married & 14 & 63.6 & 8 & 36.5 & 22 & 11.2 \\
\hline Average age & \multicolumn{2}{|c|}{28 years } & \multicolumn{2}{|c|}{22.7 years } & \multicolumn{2}{|c|}{26 years } \\
\hline \multicolumn{7}{|l|}{$\begin{array}{l}\text { Married mothers with } \\
\text { some illegitimate }\end{array}$} \\
\hline children & 14 & 87.5 & 2 & 12.5 & 16 & 8.1 \\
\hline Average age & 31. & years & 33. & years & 31. & years \\
\hline \multicolumn{7}{|l|}{$\begin{array}{l}\text { Total mothers with } \\
\text { illegitimate children }\end{array}$} \\
\hline Average age & 29. & years & 24. & years & & \\
\hline
\end{tabular}


The chi square for Table XXI is 5.793 with one degree of freedom. This is significant at the .05 level, and the null hypothesis must be rejected. Age was a contributing variable. The average age of the closed cases was less than the average age of the active cases.

The number of children was also a significant variable. The larger the number of children, the greater the tendency to remain active (Table XXII).

TABLE XXII

CHILDREN OF UNMARRIED MOTHERS

\begin{tabular}{lccc}
\hline & Active & Closed & Total \\
\hline & & & \\
Number of children of mothers never & 28 & 12 & 40 \\
married & 2 & 1.5 & 1.8 \\
$\quad$ Average per mother & 17 & 2 & 19 \\
$\begin{array}{l}\text { Number of children born out of wedlock } \\
\text { of mother with some legitimate children }\end{array}$ & 1.2 & 1 & 1.2 \\
$\quad$ Average per mother & 45 & 14 & 59 \\
$\begin{array}{l}\text { Total illegitimate children } \\
\text { Average per mother }\end{array}$ & 1.6 & 1.4 & 1.55 \\
$\begin{array}{l}\text { Number of legitimate children of mothers } \\
\text { with some children born out of wedlock }\end{array}$ & 41 & 4 & 45 \\
$\quad$ Average per mother & 2.9 & 2 & 2.8 \\
$\begin{array}{l}\text { Total children } \\
\text { Average per mother }\end{array}$ & 86 & 18 & 104 \\
\end{tabular}


The chi square for the number of children in Table XXII is 7.191 with two degrees of freedom. This is significant at the .05 level, and we must reject the null hypothesis. The average number of all children per mother was 3.1 for the cases remaining active to 1.8 for the closed cases. The percent of children remaining active was $82.7 \%$ compared to $73.6 \%$ of the mothers.

\section{Summary}

An analysis of the education level of the maternal head of the home revealed that there is no significant difference between active and closed cases. There was an observed tendency for the cases with less than eighth-grade education and more than 12 th-grade to remain active. A look in depth at the eight cases with more than 12 th-grade education revealed emotional problems that should be more fully studied but are not within the scope of this paper.

The work experience of the women was found to be a significant variable. There was a greater proportion of cases closed if the mother had experience in a trade. A chronic medical problem or receipt of vocational training for these women both had a positive relationship to closing. There was a positive relationship to remaining active if she was an unmarried mother or was considered sexually promiscuous.

The age of the mother was found to have no significance for 
opening or closing.

Family composition was found to be a significant variable.

The fewer the children, the better the chance of closing. The ages of the children was also a significant variable but difficult to interpret.

There were not enough cases receiving training or employment counseling to be significant. However it was observed that, although only $33 \%$ of the cases closed, $56 \%$ did find employment. The average age of women who closed was greater than the average age of women who remained active. The women who closed also had fewer children.

It was found that unmarried mothers had a significant tendency to remain active. It was also found that the number of children was a significant variable in the se cases remaining active. 


\section{CHAPTER V}

\section{CONCLUSIONS}

It is important to keep in mind that this was a study of a total population of cases active during one month in Linn County, Oregon. As such, conclusions can only be made in reference to this population. Findings for this population may raise questions for further study but no general conclusions can be drawn.

One of the limitations of the population studied was its size. Findings on some specific variables were obscured because so few cases were involved.

There were two variables with significance for opening or closing. Therefore the null hypothesis must be rejected. There was a difference between open and closed cases in at least two variables.

The one most pervasive difference between active and closed cases was size of family. The larger the family, the less the tendency to terminate. No mother, as the one parent head of the home with more than five children, terminated. There was a greater tendency for closing for mothers with two children than mothers with one, but the tendency to close was definite for both situations. For the study, women with no more than two children showed a better than average capacity to terminate. Such women were mostly in 
their 20's or younger so had a good chance at marriage or employment. Women with more than two children had more trouble finding work at which they could earn enough to support their larger families, or finding husbands who would assume that support. If they had more than five children, they all remained active, clearly supporting the contention that the capacity to close decreased as the number of children increased. This contention is further supported by the fact that nearly three-fourths of the children remained in the active load.

Another variable contributing to the rejection of the null hypothesis is employment experience. If a woman had only laboring experience or no work experience, she tended to remain active. Because no experience in employment was so prevalent, it became a variable of major significance. If a woman were able to overcome this deficiency, she might succeed in having her case closed. The most common reason for closing for women in this category was marriage or reconciliation. Tencases managed to close for that reason, and four closed by reason of no further contact. The major ity of the caseworkers in Linn county who have dealings with the se cases agree that no further contact cases usually get married. Thus for purposes of this study these could tentatively be included in the marriage figures. Seven of the cases found employment. The rest 
either developed other income, such as veterans benefits or Social Security, or left the state (Table XXIII).

TABLE XXIII

REASON FOR CLOSE - FEMALE HEAD OF HOUSE WITH NO PREVIOUS WORK EXPERIENCE

\begin{tabular}{|c|c|c|c|c|c|c|}
\hline $\begin{array}{c}\text { Age } \\
\text { Range }\end{array}$ & $\begin{array}{c}\text { Em - } \\
\text { ployed }\end{array}$ & $\begin{array}{l}\text { Married } \\
\text { or } \\
\text { Reconciled }\end{array}$ & $\begin{array}{l}\text { No } \\
\text { Further } \\
\text { Contact }\end{array}$ & $\begin{array}{l}\text { Other } \\
\text { Income }\end{array}$ & $\begin{array}{c}\text { Left State } \\
\text { and Other } \\
\text { Reasons }\end{array}$ & Total \\
\hline Under 20 & 1 & 3 & 1 & 0 & 0 & 5 \\
\hline $20-29$ & 2 & 4 & 3 & 0 & 2 & 11 \\
\hline $30-39$ & 2 & 1 & 0 & 1 & 1 & 5 \\
\hline $40-49$ & 1 & 2 & 0 & 1 & 1 & 5 \\
\hline $50-59$ & 1 & 0 & 0 & 0 & 0 & 1 \\
\hline Total & 7 & 10 & 4 & 2 & 4 & 27 \\
\hline
\end{tabular}

In contrast, women with experience in a trade showed a definite proclivity for closing. About half of those who closed were able to find employment, and the other half got married (Table XXIV). The younger women more frequently got married, but the older ones more frequently found work. The older women with no work experience did not readily find work (Table XXIII), and this seems to be the difference between women with no work experience and women with experience in a trade. 
TABLE XXIV

REASON FOR CLOSE - FEMALE HEAD OF HOUSE WITH EXPERIENCE IN A TRADE

\begin{tabular}{lcccccc}
\hline $\begin{array}{c}\text { Age } \\
\text { Range }\end{array}$ & $\begin{array}{c}\text { Em- } \\
\text { ployed }\end{array}$ & $\begin{array}{c}\text { Married } \\
\text { or } \\
\text { Reconciled } \\
\text { Contact }\end{array}$ & $\begin{array}{c}\text { No } \\
\text { Curther }\end{array}$ & $\begin{array}{c}\text { Other } \\
\text { Income }\end{array}$ & $\begin{array}{c}\text { Left State } \\
\text { and Other } \\
\text { Reasons }\end{array}$ & Total \\
\hline Under 20 & 0 & 3 & 0 & 0 & 0 & 3 \\
$20-29$ & 2 & 3 & 0 & 0 & 0 & 5 \\
$30-39$ & 4 & 4 & 0 & 0 & 0 & 8 \\
$40-49$ & 3 & 0 & 0 & 0 & 1 & 4 \\
$50-59$ & 1 & 0 & 0 & 0 & 0 & 1 \\
Total & 10 & 10 & 0 & 0 & 1 & 21 \\
\hline
\end{tabular}

The age of the mother revealed no significant difference between open and closed cases. Younger women did tend to terminate more readily then the older women. This may be explained by the difficulty for older women with no work experience to find work. No longer interested in or able to form a marital relationship, they have little potential to develop a resource to remove themselves from dependence on public assistance.

Although there was no significant difference between open and closed cases in the age of women who were head of the house, the very youngest and very oldest ages did not appear in the closed cases. 
Also there is a difference in average ages (Table XIV). The difference in average ages cannot be adequately accounted for by the larger families in the active cases. By dropping the cases with more than five children from the computation, the median age for the active cases becomes 34.1 and for closed cases, 31.4, indicating a real difference in the ages of the women in the active and closed cases. Another characteristic that fails to mark a significant difference between open and closed cases is education. The women with a 12 th-grade education do show some tendency to close more readily than women with less education, but women with more than 12 thgrade education had a tendency to remain active. A closer look at the cases of women with more than 12 th-grade education reveals the negative effects of failure. The case records show the se women had failed in whatever their original goals might have been. They had no other goals, so took refuge in their role of mother as a source of gratification. The education or training they had received was only incidental to their real purpose or may have been their big failure. There are several miscellaneous variables of interest. The female head of the house with experience in a trade showed a remarkable tendency to close if she had chronic medical problems (Table XIII). In the total universe of cases the tendency to close was not as pronounced but still very interesting (Table XLI). Approximately $63 \%$ remained active to $37 \%$ closed. If we restrict the cases 
to the universe of the maternal head of the home, we find a total of 34 women with chronic medical problems. Of these cases 19 remained active to 15 that closed, a ratio of $56 \%$ active to $44 \%$ closed. Considering the norm for the study of $67 \%$ active to $33 \%$ closed, this is a remarkable trend toward closing. Of the 15 women who terminated, 7 found work, 2 married, 2 reconciled with their husbands, 1 disappeared, 2 developed some other income, and 1 was terminated because no eligible child was left in the home. Of the seven that found work, four had previous work experience in a trade, but three had no previous work experience. The simple fact is that 14 of these 15 women moved to do something about their situation. The nature of their medical problems is not considered in this study.

If borne out by other studies, this would be a very revealing finding. One could reason that the medical problem provides a ready excuse for failure. As such it could provide a defense against trying in areas that are not appealing, at the same time freeing the person to try in other areas by providing a socially acceptable excuse in the event of failure.

Another variable of interest was the incidence of sexually promiscuous behavior and drinking (Table XLI). There are some questions about the reliability of the data on both questions. For the total study case records report a larger proportion of sexually promiscuous women than men. It is the reverse for drinking. This 
does not seem reasonable. There may be a problem in reporting. The information about sexual behavior of women does not usually come from the woman herself. It is usually by rumor or by information from her ex-husband. There is question about the validity of the rumors and of the information from the ex-husband. The caseworkers themselves have little occasion to observe this type of behavior.

The statistics on drinking problems were clearly out of balance. There was a drinking problem indicated in 29 cases, and 28 of these were men. It may be true that more men have drinking problems than do women, but is it valid that this many more men would be an accurate assessment of the problem? The information about the behavior of the men comes from their wives, or sometimes by rumor. Seldom do workers observe it. Occasionally a man will come into the office with a smell of alcohol on his breath. If he does, he is apt to be labeled as a man with a drinking problem. It is apparent that the se figures only represent the opinion of the caseworker as he is influenced by casual observations and the information obtained from some other person than the individual involved in the behavior. An attempt to obtain valid information on this type of conduct would have to be made from a different base than used in this study.

It is of interest to comment on the value of the training and employment counseling that is available to clients in the Linn County 
Welfare Office. The statistics indicate that there is a ratio of $68 \%$ active to $32 \%$ closed for those women who are head of the home who received training and counseling. However, this does not tell the story. There were six of the cases that remained active that found employment and were able to reduce their need for public assistance through their earnings. Adding these cases, then, to the closed cases, one finds that $56 \%$ of the cases receiving counseling and training were able to find employment or sufficient resources to reduce or eliminate need of assistance.

It is significant that of those cases that closed, only one was not employed at the time of closing although another reason may have been given for termination.

Another interesting variable was the ages of the women. The older women were more apt to close than the younger women after receiving training. The average age for the women who terminated was 34 years as against 31.2 for the women who remained active after receiving training and counseling. In the limited number of cases in this study the older women were able to use the value of training more effectively than younger women; and such a finding, if confirmed by other studies, might have some effect in the use of the training and counseling services. 


\section{Unwed Mothers}

Almost $20 \%$ of all the women in the study had one or more illegitimate children. After 15 months, $73.6 \%$ of these mothers remained active. However, it was not the fact of having illegitimate children that forced them to remain on assistance. The findings that seemed to be more important were the total number of children they had and their ages. This did not discount the impact of illegitimacy as a crisis in the life of the mother, but rather to point up the fact that apparently illegitimacy was not an impossible situation for women in this study to handle. Given youth and given a little opportunity for marriage or employment many of these mothers were able to return to some more self-supporting status. But if they had the handicap of a large number of children, then the possibility of remarriage, at least to men who could support them, and the possibility of work became remote.

\section{Indications for Further Studies}

Although there were tallies on each case for elapsed time since first application to June of 1966 , it was realized that this did not measure duration of time on public assistance rolls. It was noted in the case records that there was much activity in opening and closing. Is there an indication that cases close only to reopen 
a short time later in some instances? If so, what are the instances and is there a pattern? There would have to be further study to determine this.

One case not included in this study is an example of what is meant. The family had 13 children, the man was a laborer and his wife had done laboring work. They both had less than eighth-grade education. Their first contact with the agency came after their third child was born. This was to be only a temporary need for assistance to help them over a difficult winter. They were not seen for a number of years after that, and then returned. It became an increasing pattern of returning and requesting assistance for the winter as the number of children increased until the problem developed into a chronic welfare assistance case. The man had to leave the home as he could not face the problem of not supporting his children. One incident that contributed to this was that the family received a great deal of publicity of a negative sort after the birth of the thirteenth child. This shamed them and helped to contribute to their feeling of despair and hopelessness.

Another variable not evaluated is life style. This would include the family history, their social background, and their values and attitudes toward life and society. As pointed out by Samuel Mencher (Maas ed. 1966) until we have evaluated these characteristics, we can not plan adequately for programs to alleviate the conditions of 
poverty. The study of life style was too ambitious for this study.

The approach this study took of studying cases active during one month in one county should be expanded to achieve greater depth. The cases should be followed over a greater period of time to see what is the pattern of opening and closing and to determine what effect various programs which are offered in the county might have on this pattern.

Other studies have attempted to describe the characteristics of welfare recipients. This study had the same problem as all the other studies; to find some characteristics that can be universally applied to all cases. As pointed out by Miller (1965) this has not been satisfactorily accomplished in the other studies. This study offers little toward the establishment of any universal characteristics but does suggest the possibility of establishing characteristics that would be valid on a regional basis.

From the information in this study it can be said that a recipient of AFDC in Linn County, Oregon in June, 1966 was generally poorly educated ( $76 \%$ had less than 12 th-grade education), had poor work experience $(71 \%$ had no previous experience or only laborer experience), had a small family $(78 \%$ had 3 or less children), and was young $(77 \%$ were under the age of 40$)$.

It is not so clear just what variables influenced termination. The most common reasons for termination were employment and 
marriage or reconciliation (Table XLIX). They occurred with about equal frequency. The only two variables with significance were work experience and family composition. It is easy to understand that if a woman had a good work experience, she is apt to go to work again. Also it is obvious that if a woman is young and does not have too many children, she is apt to get married. The impact of training programs and group treatment was too slight to be significant. The role of the caseworker in personally influencing termination was not considered in this study.

This study does suggest that a certain type of case at application will have a higher than average potential for termination. Such a case will have young parents, few children, and a good work history. The presence of chronic medical problems is not an inhibiting variable nor is illegitimate pregnancy. 


\section{BIBLIOGRAPHY}

Bell, Winifred. Aid to dependent children. New York, Columbia University Press, 1965. 248 p.

Birt, Charles J. Family-centered project of St. Paul. Social Work I: $41-47$, Oct. 1956.

Blackwell, Gordon W. and Raymond F. Gould. Future citizens all. Chicago, American Public Welfare Association, 1952. 181 p.

Burchinal, Lee and Hilda Siff. Rural poverty. Journal of Marriage and the Family 26: 399-405. 1964.

Burgess, M. Elaine. Poverty and dependency: some selected characteristics. The Journal of Social Issues 31: 79-97. Jan. 1965.

Chilman, Catherine S. Growing up poor. Washington, D. C. , U.S. Dept. of Health, Education and Welfare, \#13, 1966. $117 \mathrm{p}$.

Cohen, Nathan E. Social work and social problems. New York, National Association of Social Workers, 1964. 391 p.

Cohen, Wilbur and Eugenia Sullivan. Poverty in the United States. Indicators. Washington, D. C., U.S. Dept. of Health, Education and Welfare, 1964. $7 \mathrm{p}$.

Dentler, Robert A. Major American social problems. Chicago, Rand McNally \& Co. , 1967. 530 p.

Geismar, L. L. The multi-problem family; significance of research findings. The Social Welfare Forum. New York, Columbia University Press, 1960, p. 166-179.

Glover, E. E. and J.H. Reid. Unmet and future need. The Annals of American Academy of Political and Social Science. 355: 9-19. Sept. 1964.

Gordon, Margaret S. Poverty in America. San Francisco, Chandler Publishing Co., 1965. 465 p. 
Greenleigh Associates. Facts, fallacies and future: a study of the aid to dependent children program of Cook County, Illinois. New York, Greenleigh Associates, 1960, 99 p.

Harrington, Michael. The other America. New York, The McMillan Co., 1963. $191 \mathrm{p}$.

Hatfield, Mark O. and John W. Oberdorf. A demographic analysis of the state of Or gon - prepared for the governor's co-ordinating committee on the Economic Opportunity Act. Salem, Oregon, Basic Systems, Inc., 1965. 217 p.

Hess, R. D. Educability and rehabilitation: the future of the welfare class. Journal of Marriage and the Family 26: 422-429. 1965.

Kahn, Gerald and Ellen J. Perkins. Families receiving AFDC: what do they have to live on? Welfare in Review 2: 7-15. 1964.

Kagan, M. , P. P. Hokes and U. Currin. A comparison between families wholly and partially dependent on AFDC grants. Child Welfare 45: 278-281. 1966.

Lichtenberg, Philip and Jeanne C. Pollock. Encouraging selfdetermination. Public Welfare 25: 255-261. 1967.

Lynch, John M. Trend in number of AFDC recipients 1961-1965. Welfare in Review 5:7-13. May 1967.

McCabe, A. R. Re: forty forgotten families. Public Welfare 24: 159-171. 1966.

McBroom, E. Helping AFDC families: a comparative study. Social Service Review 39: 390-398. 1965.

Maas, Henry S. (ed) Five fields of social service; reviews of research. New York, National Association of Social Workers, Inc, 1966. $208 \mathrm{p}$.

Myer, Carol H. Individualizing the multi-problem family. Social Casework 44: 267-272. 1963.

Miles, Arthur P. An introduction to public welfare. Boston, D. C. Heath \& Co., 1949. 450 p. 
Miller, H. Characteristics of AFDC families. Social Service Review 39:399-409. 1965.

Moles, O. C. Jr. Training children in low income families for school. Welfare in Review 3:1-11. June 1965.

Nordstrom, J. ADC housing costs, conditions, consequences. Smith College Studies in Social Work 35:125-154. 1965.

Parad, Howard J. Crisis intervention: selected readings. New York Family Service Association of America, 1965. 368 p.

Parrish, John B. Is U. S. realily filled with poverty; a look at the facts. U. S. News and World Reports 63:50-53. Oct. 1967.

Polansky, Norman A. Social work research. Chicago, The University of Chicago Press, 1966, p. 306.

Rein, Martin and S. M. Miller. Poverty programs and policy priorities. Transaction 4:60-71. Sept. 196.7.

Rohrlich, George F. Guaranteed minimum income proposals and the unfinished business of Social Security. The Social Service Review 41:166-178. June 1967.

Sanchez, A. The absent father in AFDC families. Public Welfare 24: 195-201. 1966.

Schorr, Alvin L. Poor kids. New York, Basic Books, 1966. 205 p.

Schorr, Alvin L. Problems in the ADC program. Social Work 5: 3-15. April 1960.

Sherwood, Clarence C. Issues in measuring results of action programs. Welfare in Review 5:13-18. August-September 1967.

Wallace, David. The Chemung County evaluation of casework service to dependent multi-problem families; another problem outcome. The Social Service Review 4.1:379-389. 1967.

Weisbrod, Burton A. (ed) The economics of poverty. Englewood Cliffs, N. J., Prentice-Hall, Inc., 1965. 180 p.

Wilensky, Harold L. and Charles N. Lebeaux. Industrial society and social welfare. New York, The Free Press, 1965. 397 p. 
Youngman, L. C. Social group work in the AFDC program. Public Welfare 23: 25-31, 59-61. 1965.

- Abstracts for Social Workers, Vol. I no, 1, 1965 to Vol. II no. 2, 1967.

- Abstracts of Research and Demonstration Projects in Social Welfare and Related Fields. Washington, D. C., U. S. Bureau of Family Services. n.d.

- Bulletin of the Public Affairs Information Ser vice, $1958-1967$.

- Converging social trends, emerging social problems. Washington, D, C., Welfare Administration, Division of Research, \#6, 1964.

- Having the power we have the duty. Washington, D. C., report to the secretary of Health, Education and Welfare by The Advisory Council on Public Welfare, 1966. 148 p.

- National blueprint for public welfare. Washington, D. C.., Health, Education and Welfare. Indicators, November 1966, $21 \mathrm{p}$.

- Oregon blue book, 1967-68. Salem, Oregon, State of Oregon (n, d.) 300 p.

- Poverty; four approaches--four solutions:

Proceedings of the First Annual Conference on Social Issues at the University of Oregon, Eugene, 1966. Eugene, Oregon, Associated Students of the University of Oregon, 1966. 89. p.

- Social development. Washington, D. C., Welfare Administration - Division of Research, \#15, 1966.

- Social sciences and humanities index. April 1958 to Sept. 1967. 
APPENDIX 
TABLE XXV

NUMBER OF CASES IN STUDY

Active Closed $\begin{gathered}\text { Total Active Transfers Total } \\ \text { and Closed }\end{gathered}$

\begin{tabular}{lccccc}
\hline Female Head & 106 & 52 & 158 & 7 & 165 \\
Male Head & 1 & 2 & 3 & 3 & 6 \\
Both Parents & 27 & 12 & 39 & 2 & 41 \\
Total Cases & 134 & 66 & 200 & 12 & 212 \\
\hline
\end{tabular}

TABLE XXVI

TABLE OF MEANS

Universe of Cases

Status of Case

Active Closed Transfers

Children Ever Born per Family

3.7

2.63

3.75

Children in Home per Family

3.54

2.63

3.75

Age Adult Male in Home

40.5

40.7

43.75

Age Adult Female in Home

36.6

32.8

33.9

Age Child in Home

9.8

9.9

9.6

Adult Education Male

7.6

8.5

4.8

Adult Education Female

9

9.76

9.6

Time Since First Application

5.2 yrs

$3.5 \mathrm{yrs}$

$1.6 \mathrm{yrs}$ 
TABLE XXIX

AGES ALL ADULTS

\begin{tabular}{|c|c|c|c|c|c|c|c|c|c|c|}
\hline & \multicolumn{2}{|c|}{ Active } & \multicolumn{2}{|c|}{ Closed } & \multicolumn{2}{|c|}{$\begin{array}{l}\text { Total Active } \\
\text { and Closed }\end{array}$} & \multicolumn{2}{|c|}{ Transfers } & \multicolumn{2}{|c|}{ Total } \\
\hline & $\mathrm{M}$ & $F$ & M & $F$ & $\mathrm{M}$ & $F$ & $\mathrm{M}$ & $F$ & $\mathrm{M}$ & $F$ \\
\hline Under 20 & 2 & 3 & 0 & 6 & 2 & 9 & 0 & 0 & 2 & 9 \\
\hline $20-29$ & 15 & 41 & 13 & 20 & 28 & 61 & 2 & 3 & 30 & 64 \\
\hline $30-39$ & 25 & 40 & 13 & 22 & 38 & 62 & 1 & 5 & 39 & 67 \\
\hline $40-49$ & 18 & 33 & 14 & 14 & 32 & 47 & 1 & 2 & 33 & 49 \\
\hline $50-59$ & 13 & 15 & 2 & 2 & 15 & 17 & 4 & 1 & 19 & 18 \\
\hline $60-69$ & 7 & 1 & 1 & 0 & 8 & 1 & 0 & 0 & 8 & 1 \\
\hline $70-79$ & 2 & 0 & 0 & 0 & 2 & 0 & 0 & 0 & 2 & 0 \\
\hline Total & 82 & 133 & 43 & 64 & 125 & 197 & 8 & 11 & 133 & 208 \\
\hline
\end{tabular}

TABLE XXVIII

AGES OF ADULTS IN GRANTS

\begin{tabular}{|c|c|c|c|c|c|c|c|c|c|c|}
\hline & \multicolumn{2}{|c|}{ Active } & \multicolumn{2}{|c|}{ Closed } & \multicolumn{2}{|c|}{$\begin{array}{l}\text { Total Active } \\
\text { and Closed }\end{array}$} & \multicolumn{2}{|c|}{ Transfers } & \multicolumn{2}{|c|}{ Total } \\
\hline & $\mathrm{M}$ & $F$ & M & $F$ & M & $F$ & $\mathrm{M}$ & $\mathrm{F}$ & M & $F$ \\
\hline Under 20 & 2 & 3 & 0 & 6 & 2 & 9 & 0 & 0 & 2 & 9 \\
\hline $20-29$ & 14 & 40 & 2 & 20 & 17 & 60 & 2 & 3 & 19 & 63 \\
\hline $30-39$ & 11 & 39 & 3 & 22 & 14 & 61 & 1 & 5 & 15 & 66 \\
\hline $40-49$ & 5 & 33 & 6 & 14 & 11 & 47 & 1 & 0 & 12 & 47 \\
\hline $50-59$ & 9 & 15 & 2 & 2 & 11 & 17 & 4 & 1 & 15 & 18 \\
\hline $60-69$ & 5 & 1 & 1 & 0 & 6 & 1 & 0 & 0 & 6 & 1 \\
\hline $70-79$ & 2 & 0 & 0 & 0 & 2 & 0 & 0 & 0 & 2 & 0 \\
\hline Total & 49 & 131 & 14 & 64 & 63 & 195 & 8 & 9 & 71 & 204 \\
\hline
\end{tabular}


TABLE XXIX

EDUCATION LEVEL BY AGE OF FEMALE ADULTS

Universe of Cases

\begin{tabular}{llllll}
\hline Age Range & -8 & 8 & $8-11$ & 12 & $\begin{array}{c}\text { Voc. College Total } \\
\text { Trng. }\end{array}$ \\
\hline
\end{tabular}

Education Level of Active Cases

$\begin{array}{lrrrrrr}60-69 & 1 & & & & & 1 \\ 50-59 & 6 & 4 & 4 & 2 & & 16 \\ 40-49 & 12 & 5 & 9 & 7 & 33 \\ 30-39 & 5 & 13 & 11 & 7 & 1 & 38 \\ 20-29 & 1 & 2 & 25 & 10 & & 3 \\ \text { Under 20 } & & & 3 & & 3 & 130 \\ \text { Total } & 25 & 24 & 52 & 26 & & \\ \text { Mean Education - } & & & & & \end{array}$

Education Level of Closed Cases

60-69

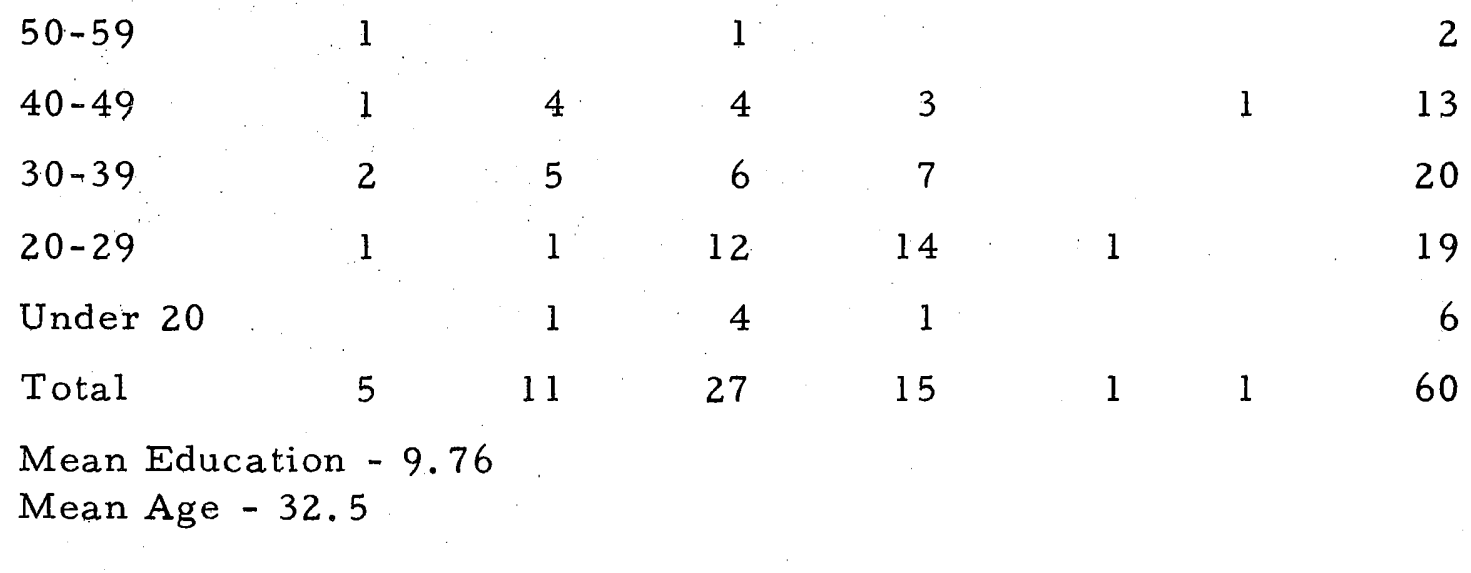


TABLE XXX

NUMBER OF CHILDREN KNOWN EVER BORN

BY AGE OF CHILD

\begin{tabular}{lccccc}
\hline & Active & Closed & $\begin{array}{c}\text { Total Active } \\
\text { and Closed }\end{array}$ & Transfers & Total \\
\hline $0-6$ & 146 & 52 & 198 & 13 & 211 \\
$7-11$ & 136 & 54 & 190 & 15 & 205 \\
$12-16$ & 107 & 30 & 137 & 12 & 149 \\
$16-20$ & 102 & 35 & 137 & 5 & 142 \\
Over 20 & 2 & 3 & 5 & 0 & 5 \\
Total & 493 & 174 & 667 & 45 & 712 \\
\hline
\end{tabular}

* Not precise due to possible neglect in reporting or recording children not in home. 
TABLE XXXI

NUMBER OF FAMILIES BY NUMBER OF CHILDREN AND

TIME SINCE FIRST APPLICATION

Universe of Cases

\begin{tabular}{|c|c|c|c|c|c|c|c|c|}
\hline \multirow{2}{*}{$\begin{array}{l}\text { Time Since } \\
\text { First Appli- } \\
\text { cation to } \\
6-66 \text { in Years }\end{array}$} & & \multicolumn{5}{|c|}{ Closed Cases } & & \multirow[t]{2}{*}{$\begin{array}{c}\text { Total } \\
\text { Families }\end{array}$} \\
\hline & 1 & 2 & 3 & 4 & 5 & 6 & 7 & \\
\hline 20 & & 1 & & & & & & 1 \\
\hline 19 & & & & & & & & \\
\hline 18 & & & & & & & & \\
\hline 17 & & & & & & & & \\
\hline 16 & & & & & & & & \\
\hline 15 & & & & & & & & \\
\hline 14 & & & & & 1 & & & 1 \\
\hline 13 & & & & & & & & \\
\hline 12 & & & & & & & & \\
\hline 11 & & & & & & & & \\
\hline 10 & & 1 & & & & & & 1 \\
\hline 9 & & & & 1 & & & & 1 \\
\hline 8 & & 1 & & & & & & 1 \\
\hline 7 & 1 & 1 & & 1 & 1 & & & 4 \\
\hline 6 & 2 & & 1 & & 3 & & & 6 \\
\hline 5 & 1 & 5 & 2 & & 1 & & & 9 \\
\hline 4 & 2 & 1 & & & & & & 3 \\
\hline 3 & & 1 & 1 & 1 & 1 & & & 4 \\
\hline 2 & & 3 & 1 & & & & & 4 \\
\hline Up to $1 \mathrm{yr}$. & 10 & 10 & 4 & 3 & 1 & 2 & 1 & 31 \\
\hline Total Families & 16 & 24 & 9 & 6 & 8 & 2 & 1 & 66 \\
\hline
\end{tabular}

Mean Number Children per Family - 2.6 Children

Mean Time Since First Application - 3.5 years 
TABLE XXXII

NUMBER OF FAMILIES BY NUMBER OF CHIIDREN AND TIME SINCE FIRST APPLICATION

Universe of Cases

\begin{tabular}{|c|c|c|c|c|c|c|c|c|c|c|c|c|}
\hline $\begin{array}{l}\text { Time Since } \\
\text { First Appli- } \\
\text { cation to } \\
6-66 \text { in Years }\end{array}$ & $\begin{array}{l}\mathrm{Nu} \\
1\end{array}$ & mber & of & $\begin{array}{l}\text { Acti } \\
\text { Child }\end{array}$ & $\begin{array}{l}\text { ve } \\
\text { lren }\end{array}$ & Jase & wn & $\mathrm{E}_{\mathrm{v}}$ & er & Bo & 11 & $\begin{array}{c}\text { Total } \\
\text { Families }\end{array}$ \\
\hline 20 & & & & & & & & & & & & \\
\hline 19 & & & & & 1 & & & & & & & 1 \\
\hline 18 & & & 1 & & & & & & & 1 & & 2 \\
\hline 17 & & & 2 & & & & & & & & & 2 \\
\hline 16 & 1 & & 1 & & & & 1 & 1 & & & & 4 \\
\hline 15 & & & 1 & 1 & & & & & & & & 2 \\
\hline 14 & & & & & & & & & & & & \\
\hline 13 & & & & & & & 1 & & & & & 1 \\
\hline 12 & & & & 1 & & & & 1 & & & & 2 \\
\hline 11 & & & 1 & & 1 & & & & & & & 2 \\
\hline 10 & & 1 & 1 & & & & & & & & & 2 \\
\hline 9 & 1 & 1 & 4 & 1 & & & & & & & & 7 \\
\hline 8 & & 1 & 2 & 2 & & 1 & & & & & 1 & 7 \\
\hline 7 & 1 & 2 & & & 1 & & 1 & 1 & & & & 6 \\
\hline 6 & & 1 & 1 & 2 & 2 & 2 & & & & & & 8 \\
\hline 5 & 1 & 1 & 3 & 2 & 3 & 1 & 3 & & & & & 14 \\
\hline 4 & 1 & 2 & 4 & 2 & 3 & & 1 & & & & & 13 \\
\hline 3 & 3 & 2 & 2 & 1 & & & 2 & 1 & 1 & & & 12 \\
\hline 2 & 3 & 4 & 4 & 3 & 2 & 2 & & & & 1 & & 19 \\
\hline $\mathrm{Up}$ to $1 \mathrm{yr}$. & 8 & 5 & 5 & 9 & 1 & 2 & & & & & & 30 \\
\hline Total Families & 19 & 20 & 32 & 24 & 14 & 8 & 9 & 4 & 1 & 2 & 1 & 134 \\
\hline
\end{tabular}

Mean Number Children per Family - 3.7 children

Mean Time Since First Application per Family - 5.2 years 
TABLE XXXIII

NUMBER OF CHILDREN IN GRANT BY AGE OF CHILD

\begin{tabular}{lrrrrr}
\hline & Active & Closed & $\begin{array}{c}\text { Total Active } \\
\text { and Closed }\end{array}$ & Transfers & Total \\
\hline $0-6$ & 146 & 52 & 198 & 13 & 211 \\
$7-11$ & 134 & 54 & 188 & 15 & 203 \\
$12-15$ & 106 & 29 & 135 & 12 & 147 \\
$16-20$ & 86 & 34 & 120 & 5 & 125 \\
Over 20 & 2 & 2 & 4 & 0 & 4 \\
Total & 474 & 171 & 645 & 45 & 690 \\
\hline
\end{tabular}

TABLE XXXIV

REASON FOR NEED

Active Closed $\begin{gathered}\text { Total Active } \\ \text { and Closed }\end{gathered}$ Transfers Total

Death of Male $\quad 4$

of Female

$1 \quad 4$

0

4

ility

Disability

$\begin{array}{lrrrrr}\text { of Male } & 30 & 17 & 47 & 4 & 51 \\ \text { of Female } & 2 & 6 & 8 & 0 & 8\end{array}$

Continued Absence

$\begin{array}{crrrrr}\text { Separated Male } & 62 & 33 & 95 & 3 & 98 \\ \text { Female } & 0 & 0 & 0 & 3 & 3 \\ \text { Divorced - Male } & 40 & 21 & 61 & 4 & 65 \\ \text { Female } & 1 & 1 & 2 & & 2 \\ \text { Total } & 139 & 79 & 218 & 14 & 232 \\ \text { Number of cases* } & 134 & 66 & 200 & 12 & 212\end{array}$

* Number of cases is less than total because of frequency of combined factors such as both adults disabled or disability and continued absence. 
TABLE XXXV

EDUCATION - ALL ADULTS *

Active Closed $\begin{gathered}\text { Total Active } \\ \text { and Closed fers }\end{gathered} \quad$ Totals

Less than 8 th

Male

8 th Grade

Male

Female

$8-12$

Male

Female

12 th

Male
Female

Vocational Training

Male

Female

Some College

Male

Female

Total

204

21

24

15

23

50

17

27

0

3
4

25

29

4

29

5

5

20

35

2

37

12

19

28

28

7

16

0

1

4

4

$\begin{array}{lll}24 & 2 & 26 \\ 43 & 3 & 46\end{array}$

21

7

38

81

$\begin{array}{lll}78 & 3 & 81\end{array}$

6 6 
TABLE XXXVI

EDUCATION - ADULTS IN GRANT

Active Closed $\begin{gathered}\text { Total Active } \\ \text { and Closed frans- }\end{gathered}$ Total

Less than 8 th Grade

Male

Female

8 th Grade

Male

Female

8-12th Grade

Male

Female

12th Grade

Male

Female

Vocational Training

Male

Female

3

1

4

4

Some College

Male

Female

Unknown - Male

Female

Total - Male

Total - Female

Total
123

$24 \quad 5$

53

$24 \quad 12$

5

54

28

16

5

38

3
85

\section{5}

41

9


TABLE XXXVII

WORK EXPERIENCE - ALL ADULTS

Active Closed $\begin{aligned} & \text { Total Active Trans- } \\ & \text { and Closed fers }\end{aligned} \quad$ Total

Labor

$\begin{array}{lrrrrr}\text { Male } & 56 & 30 & 86 & 8 & 94 \\ \text { Female } & 17 & 4 & 21 & 2 & 23\end{array}$

Trade

$\begin{array}{lrrrrr}\text { Male } & 16 & 7 & 23 & 0 & 23 \\ \text { Female } & 22 & 25 & 47 & 2 & 49\end{array}$

No Experience

$\begin{array}{lrrrrr}\text { Male } & 0 & 0 & 0 & 0 & 0 \\ \text { Female } & 91 & 35 & 126 & 5 & 131\end{array}$

Total

\begin{tabular}{lrrrrr} 
Male & 72 & 37 & 109 & 8 & 117 \\
Female & 130 & 64 & 194 & 9 & 203 \\
& 202 & 101 & 303 & 17 & 320 \\
\hline
\end{tabular}


TABLE XXXVIII

WORK EXPERIENCE - ADULTS IN GRANT

$$
\text { Active Closed } \begin{aligned}
& \text { Total Active Trans- } \\
& \text { and Closed fers }
\end{aligned} \quad \begin{gathered}
\text { Total } \\
\text { fos }
\end{gathered}
$$

Labor

$\begin{array}{lrrrrr}\text { Male } & 22 & 12 & 34 & 5 & 39 \\ \text { Female } & 17 & 4 & 21 & 2 & 23\end{array}$

Trade

$\begin{array}{lrrrrr}\text { Male } & 5 & 1 & 6 & & 6 \\ \text { Female } & 22 & 24 & 46 & 2 & 48\end{array}$

No Experience

Male

Female

$91 \quad 34$

125

5

130

Unknown

\begin{tabular}{|c|c|c|c|}
\hline Male & 1 & & 1 \\
\hline Female & 3 & 3 & \\
\hline
\end{tabular}

Total

\begin{tabular}{lrrrrr} 
Male & 28 & 13 & 41 & 5 & 46 \\
Female & 133 & 65 & 198 & 9 & 207 \\
& 161 & 78 & 239 & 14 & 253 \\
\hline
\end{tabular}


TABLE XXXIX

EDUCATION OF FEMALE HEAD OF HOUSE WITH EXPERIENCE IN A TRADE

\begin{tabular}{|c|c|c|c|}
\hline \multirow{2}{*}{$\begin{array}{l}\text { Education Level } \\
\text { in Years }\end{array}$} & \multicolumn{3}{|c|}{ Number of Women } \\
\hline & Active & Closed & Total \\
\hline Less than 8 & 0 & 2 & 2 \\
\hline 8 & 3 & 0 & 3 \\
\hline $9-11$ & 6 & 8 & 14 \\
\hline Completed GED by $9 / 67$ & 4 & 2 & 6 \\
\hline 12 & 6 & 7 & 13 \\
\hline $12+$ & 3 & 2 & 5 \\
\hline Total & 22 & 21 & 43 \\
\hline $\begin{array}{l}\text { Mean Level W/GED as } 12 \\
\text { years }\end{array}$ & $\begin{array}{r}11.2 \\
\text { yrs }\end{array}$ & $\begin{array}{r}10.7 \\
\text { yrs }\end{array}$ & $\begin{array}{r}10.9 \\
\text { yrs }\end{array}$ \\
\hline $\begin{array}{l}\text { Mean Level W/GED as } \\
\text { High School Dropout }\end{array}$ & $\begin{array}{r}10.8 \\
\text { yrs }\end{array}$ & $\begin{array}{r}10.5 \\
\text { yrs }\end{array}$ & $\begin{array}{r}10.6 \\
\text { yrs }\end{array}$ \\
\hline
\end{tabular}

TABLE XL

NUMBER OF ILLEGITIMATE CHILDREN BY SIZE OF FAMILY OF FEMALE HEAD OF HOUSE WITH TRADE

\begin{tabular}{ccccc}
\hline $\begin{array}{c}\text { Family } \\
\text { Size }\end{array}$ & $\begin{array}{c}\text { Number Children } \\
\text { Total } \\
\text { Children }\end{array}$ & $\begin{array}{c}\text { Number } \\
\text { Illgeiti- } \\
\text { mate }\end{array}$ & Active & Closed \\
\hline 1 & 5 & 5 & 5 & 0 \\
2 & 2 & 2 & 1 & 0 \\
3 & 9 & 5 & 3 & 0 \\
4 & 0 & 0 & 0 & 0 \\
5 & 5 & 5 & 1 & 0 \\
6 & 6 & 1 & 1 & 0 \\
Total & 27 & 18 & 11 & 0 \\
\hline
\end{tabular}


TABLE XLI

ADULT BEHAVIOR PROBLEMS

\begin{tabular}{|c|c|c|c|}
\hline Active & Closed & $\begin{array}{l}\text { Total Active } \\
\text { and Closed }\end{array}$ & $\begin{array}{l}\text { Trans- } \\
\text { fers }\end{array}$ \\
\hline
\end{tabular}

In Jail

$\begin{array}{lllll}\text { Male } & 6 & 4 & 10 & 10\end{array}$

Female

Sexually Promiscuous

$\begin{array}{lrrrrr}\text { Male } & 6 & 3 & 9 & 1 & 10 \\ \text { Female } & 12 & 3 & 15 & & 15\end{array}$

Drinking

Male.

20

8

28

2

30

Female

1

1

1

2

Other Delinquent Acts

Male

8

5

13

14

Female

1

1

Chronic Medical

Problems

Male

21

9

30

4

34

Female

27

16

43

1

44

Number Women

Illegitimately

Pregnant

28

10

38

39

Number Illegiti-

mate Births

45

14

59

60

Paternity

Acknowledged

4

0 .

4

4 
TABLE XLII

NUMBER OF' CHILDREN WITH CHILD PROBLEMS

Active Closed $\begin{gathered}\text { Total Active } \\ \text { and Closed }\end{gathered} \begin{gathered}\text { Trans- } \\ \text { fers }\end{gathered} \quad$ Total

Chronic Medical

Problem

0

6

$6 \quad 1$

7

Truant

14

1

15

15

Other Delinquent

Acts

10

10

10

Total

14

17

31

1

32 
TABLE XLIII

FEMALE HEAD OF HOUSE

SIZE FAMILY

\begin{tabular}{cccc}
\hline $\begin{array}{c}\text { Number of } \\
\text { Children }\end{array}$ & Active & Number of Families & \\
\hline 1 & 18 & Closed & Total \\
2 & 18 & 15 & 33 \\
3 & 28 & 21 & 39 \\
4 & 13 & 8 & 36 \\
5 & 13 & 4 & 17 \\
6 & 8 & 4 & 17 \\
7 & 5 & 0 & 8 \\
8 & 1 & 0 & 5 \\
9 & 1 & 0 & 1 \\
10 & 1 & 0 & 1 \\
Total & 106 & 0 & 3 \\
Mean Number & 3.4 & 52 & 158 \\
Children & & 2.2 & \\
\hline
\end{tabular}


TABLE XLIV

ABSENT FATHERS

\begin{tabular}{|c|c|c|c|c|c|}
\hline & Active & Closed & $\begin{array}{c}\text { Total Active } \\
\text { and Closed }\end{array}$ & $\begin{array}{l}\text { Trans- } \\
\text { fers }\end{array}$ & Total \\
\hline \multicolumn{6}{|l|}{ Number Absent } \\
\hline Fathers & 100 & 53 & 153 & 7 & 160 \\
\hline \multicolumn{6}{|l|}{ Number of } \\
\hline Children & 339 & 119 & 458 & 26 & 484 \\
\hline \multicolumn{6}{|l|}{ Fathers with } \\
\hline \multicolumn{6}{|l|}{ Court Order to } \\
\hline Support & 37 & 17 & 54 & 1 & 55 \\
\hline Number of Children & 127 & 33 & 160 & 7 & 167 \\
\hline \multicolumn{6}{|l|}{ Number Fathers } \\
\hline Supporting & 20 & 10 & 30 & 0 & 30 \\
\hline Number Children & 68 & 21 & 89 & 0 & 89 \\
\hline
\end{tabular}


TABLE XLV

NUMBER OF CHILDREN BY AGE OF MOTHER AND AGE OF CHILDREN IN FAMILY WITH FEMALE HEAD

\begin{tabular}{|c|c|c|c|c|c|c|c|c|}
\hline \multirow{3}{*}{$\begin{array}{l}\text { Age Range } \\
\text { of Mother }\end{array}$} & \multicolumn{8}{|c|}{ Age Range of Children } \\
\hline & \multicolumn{2}{|c|}{$0-6$} & \multicolumn{2}{|c|}{$7-11$} & \multicolumn{2}{|c|}{$12-15$} & \multicolumn{2}{|c|}{ over 16} \\
\hline & $\because A *$ & $C *$ & A & $\mathrm{C}$ & A & $\mathrm{C}$ & A & $\mathrm{C}$ \\
\hline Under 20 & 3 & 7 & & & & & & \\
\hline $20-29$ & 77 & 25 & 23 & 7 & 2 & 2 & & \\
\hline $30-39$ & 32 & 7 & 42 & 20 & 37 & 9 & 14 & 11 \\
\hline $40-49$ & 15 & 2 & 25 & 6 & 32 & 5 & 30 & 7 \\
\hline $50-59$ & 3 & 0 & 3 & 0 & 7 & 1 & 14 & 4 \\
\hline
\end{tabular}

$* \mathbf{A}=$ Active; $\mathbf{C}=$ Closed

TABLE XLVI

NUMBER OF MOTHERS BY AGE OF MOTHERS AND AGE OF CHILDREN IN FAMILY WITH FEMALE HEAD

\begin{tabular}{lrrrrrrrr}
\hline $\begin{array}{l}\text { Age Range } \\
\text { of Mother }\end{array}$ & $\begin{array}{c}0 \\
\text { A }\end{array}$ & A $*$ & \multicolumn{8}{c}{ Age Range of Children } \\
& C * & A & C & A & C & A & C \\
\hline Under 20 & 3 & 6 & & & & & & \\
$20-29$ & 36 & 15 & 13 & 6 & 2 & 2 & & \\
$30-39$ & 20 & 6 & 25 & 12 & 21 & 8 & 8 & 7 \\
$40-49$ & 10 & 2 & 16 & 5 & 20 & 4 & 18 & 4 \\
$50-59$ & 2 & & 2 & & 4 & 1 & 7 & 2 \\
\hline
\end{tabular}

$* \mathrm{~A}=$ Active; $\mathrm{C}=\mathrm{Closed}$ 
TABLE XLVII

GROUP TREATMENT

Active Closed $\begin{gathered}\text { Total Active } \\ \text { and Closed }\end{gathered} \begin{gathered}\text { Trans- } \\ \text { fers }\end{gathered} \quad$ Total

Referred to Group

$\begin{array}{lrrrrr}\text { Male } & 0 & 0 & 0 & 0 & 0 \\ \text { Female } & 31 & 13 & 44 & 2 & 46\end{array}$

Completed

Treatment

19

$6 \quad 25$

25

TABLE XLVIII

CASE REFERRED FOR VOCATIONAL TRAINING

Active Closed Total Active Trans- $\begin{gathered}\text { Total } \\ \text { and Closed fers }\end{gathered}$

Referred

$\begin{array}{lrrrrr}\text { Male } & 21 & 6 & 27 & 2 & 29 \\ \text { Female } & 93 & 48 & 141 & 4 & 145\end{array}$

Completed GED

$\begin{array}{lrrrrr}\text { Male } & 0 & 1 & 1 & 0 & 1 \\ \text { Female } & 23 & 6 & 29 & 1 & 30\end{array}$

Trained for Job

$\begin{array}{lrrrrr}\text { Male } & 3 & 0 & 3 & 1 & 4 \\ \text { Female } & 16 & 5 & 21 & 0 & 21\end{array}$

Found Job

\begin{tabular}{lrrrrr} 
Male & 3 & 0 & 3 & 1 & 4 \\
Female & 7 & 5 & 12 & 0 & 12 \\
\hline
\end{tabular}


TABLE XLIX

REASON FOR CLOSE - ALL WOMEN

\begin{tabular}{|c|c|c|c|c|c|}
\hline & $\begin{array}{c}\text { Work } \\
\text { Female }\end{array}$ & $\begin{array}{l}\text { Work } \\
\text { Male }\end{array}$ & $\begin{array}{l}\text { Marriage or } \\
\text { Reconciled }\end{array}$ & $\begin{array}{c}\text { Lost } \\
\text { Contact }\end{array}$ & Other \\
\hline
\end{tabular}

Age

Under 20

1

20-29

6

30-39

7

40-49

7

2

50-59

2

Work Experience

Laborer

Trade

No experience

Education

8 th or less

9 th -11 th

12 th or more

Reason for Need

Disabled spouse

Divorce

Separated

Unmarried

Rec'd voc. tring.

Rec'd grp. treat-
5

2

13

8

6

7

10

10

5

3

3

1
3.

6

13

3

3

4

33

2

6

3

$\begin{array}{rr}1 & 3 \\ 2 & 13 \\ & 6\end{array}$

$\begin{array}{ll}4 & 3 \\ 2 & 7 \\ - & 2\end{array}$

11 